\title{
Assessment of groundwater quality for drinking and irrigation use in shallow hard rock aquifer of Pudunagaram, Palakkad District Kerala
}

\author{
V. Satish Kumar • B. Amarender • Ratnakar Dhakate • \\ S. Sankaran · K. Raj Kumar
}

Received: 24 February 2014 / Accepted: 10 June 2014/Published online: 15 June 2014

(C) The Author(s) 2014. This article is published with open access at Springerlink.com

\begin{abstract}
Groundwater samples were collected for premonsoon and post-monsoon seasons based on the variation in the geomorphological, geological, and hydrogeological factors for assessment of groundwater quality for drinking and irrigation use in a shallow hard rock aquifer of Pudunagaram area, Palakkad district, Kerala. The samples were analyzed for various physico-chemical parameters and major ion chemistry. Based on analytical results, Gibbs diagram and Wilcox plots were plotted and groundwater quality has been distinguished for drinking and irrigation use. Gibbs diagram shows that the samples are rock dominance and controlling the mechanism for groundwater chemistry in the study area, while Wilcox plot suggest that most of the samples are within the permissible limit of drinking and irrigation use. Further, the suitability of water for irrigation was determined by analyzing sodium adsorption ratio, residual sodium carbonate, sodium percent $(\% \mathrm{Na})$, Kelly's ratio, residual sodium carbonate, soluble sodium percentage, permeability index, and water quality index. It has been concluded that, the water from the study area is good for drinking and irrigation use, apart few samples which are exceeding the limits due to anthropogenic activities and those samples were indisposed for irrigation.
\end{abstract}

Keywords Sodium absorption ratio (SAR) $\cdot$ Kelly's ratio (KR) - Residual sodium carbonate (RSC) - Soluble sodium percentage (SSP) · Permeability index (PI) - Water quality index (WQI)

V. Satish Kumar $(\bowtie) \cdot$ B. Amarender · R. Dhakate

S. Sankaran · K. Raj Kumar

CSIR-National Geophysical Research Institute, Uppal Road, Hyderabad 500007, India

e-mail: satishkumar3113@gmail.com

\section{Introduction}

Groundwater is generally less susceptible to contamination than surface water; it is usually highly mineralized in its natural state. As water moves slowly through the subsurface porous media, it can remain for extended periods of time in contact with minerals present in the soil and bedrock and become saturated with dissolved solids from these minerals. This dissolution process continues until chemical equilibrium is reached between the water and the minerals with which it is in contact. The resource can be optimally used and sustained only when the quantity and quality of the groundwater is assessed. In this present scenario, the increasing population is leading to the over exploitation of resources resulting to their decline. One such commodity is the scarcity of the water resources. The anthropogenic disturbances through industrial and agricultural pollution, increasing consumption and urbanization degrade the groundwater and impair their use for drinking, agricultural, industrial and domestic uses (Carpenter et al. 1998; Jarvie et al. 1998; Simeonov et al. 2003).

The problems with groundwater quality are more acute in areas that are densely populated and thickly industrialized and have shallow groundwater tube wells (Shivran et al. 2006). Geochemical studies of groundwater provide better understanding of possible changes in quality as development progresses. The suitability of groundwater for domestic and irrigation purposes is determined by its geochemistry. Quality being on a high note for the survival of the humans as well as all the living beings made us to switch over to the methods for assessing the groundwater quality. There is no doubt that water and sustainable development is inextricably linked.

A number of studies on groundwater and surface water quality with respect to drinking and irrigation purposes have been carried out in different parts of India and around 
the world with reference to major ion chemistry, trace element chemistry and through multivariate statistical techniques. Naik et al. (2009) carried out the groundwater study in Koyna river basin and conclude that the groundwater samples are dominated by alkaline earth elements, the shallow aquifers groundwater samples are generally $\mathrm{Ca}-\mathrm{HCO}_{3}$ and $\mathrm{Ca}-\mathrm{Mg}-\mathrm{HCO}_{3}$ type, whereas deeper aquifer groundwater samples are $\mathrm{Ca}-\mathrm{Mg}-\mathrm{HOC}_{3}$ and $\mathrm{Na}-\mathrm{HCO}_{3}$ type. Most of the groundwater sample is generally fit for drinking and irrigation purposes. Takem et al. (2010) carried out groundwater study from springs and bore wells in a alluvial aquifer and conclude that the area is contaminated with nitrate pollution due to anthropogenic activities. Purushotham et al. (2011) has carried out similar studies of groundwater and conclude that the groundwater deteriorated due to rapid urbanization. Suyash and Pawar (2011) has carried out accentuation of heavy metals in groundwater and its spatio-temporal variation through using GIS techniques in Ankaleshwar industrial estate, India and conclude that the GIS techniques have facilitated the monitoring of spatio-temporal behaviors of heavy metals and site-specific accretion pattern using raster and color composite maps of shallow groundwater system.

Recently various researchers have carried out groundwater study for drinking and irrigation water standards using different indices and plots (Rao and Rao 2010; Rao et al. 2012; Bhardwaj and Sen Singh 2011; Prasanna et al. 2011; Akbal et al. 2011; Nosrati and Van Den Eeckhaut 2012; Sharma et al. 2012; Gupta et al. 2012). Besides these, Machender et al. (2013) have carried out groundwater and surface water study in a Chinnearu river basin to distinguish the groundwater and surface water for drinking and irrigation use. He concludes that most of the groundwater samples are within permissible limits of drinking and irrigation use. The samples that have higher concentration are due to water-rock interaction. Besides these, extensive studies on water quality have been carried out by various workers (Majumdar and Gupta 2000; Dasgupta and Purohit 2001; Khurshid et al. 2002; Sujatha and Reddy 2003; Aravindan et al. 2004, 2010; Sreedevi 2004; Sunitha et al. 2005; Subba Rao 2006; Shankar et al. 2010, 2011).

To evaluate the groundwater quality and to have sustainable development a proper quality assessment has to be carried out. The main objective of the article is to determine the groundwater quality for drinking and irrigation purposes, and compared the chemical analysis data of the groundwater with the water quality standards.

\section{Study area}

The Pudunagaram study area, Palakkad District, Kerala, lies between $10^{\circ} 38^{\prime}-10^{\circ} 42^{\prime} \mathrm{N}$ Latitude and $76^{\circ} 37^{\prime}-76^{\circ} 43^{\prime} \mathrm{E}$ Longitude in Survey of India Toposheet No. 58 B/10. Topographically, the study area is a midland and has flat topography. The elevation is varying from 75 to $125 \mathrm{~m}$ above mean sea level. Elevation is gradually increasing from west to east in the study area (Fig. 1). The soil type is laterite at the hills and in midland regions. Midland area is thickly cultivated with paddy, coconut, arecanut, cashew and pepper. The study area experiences humid type of climate and very hot during the month from March to June

Fig. 1 Location map of the study area

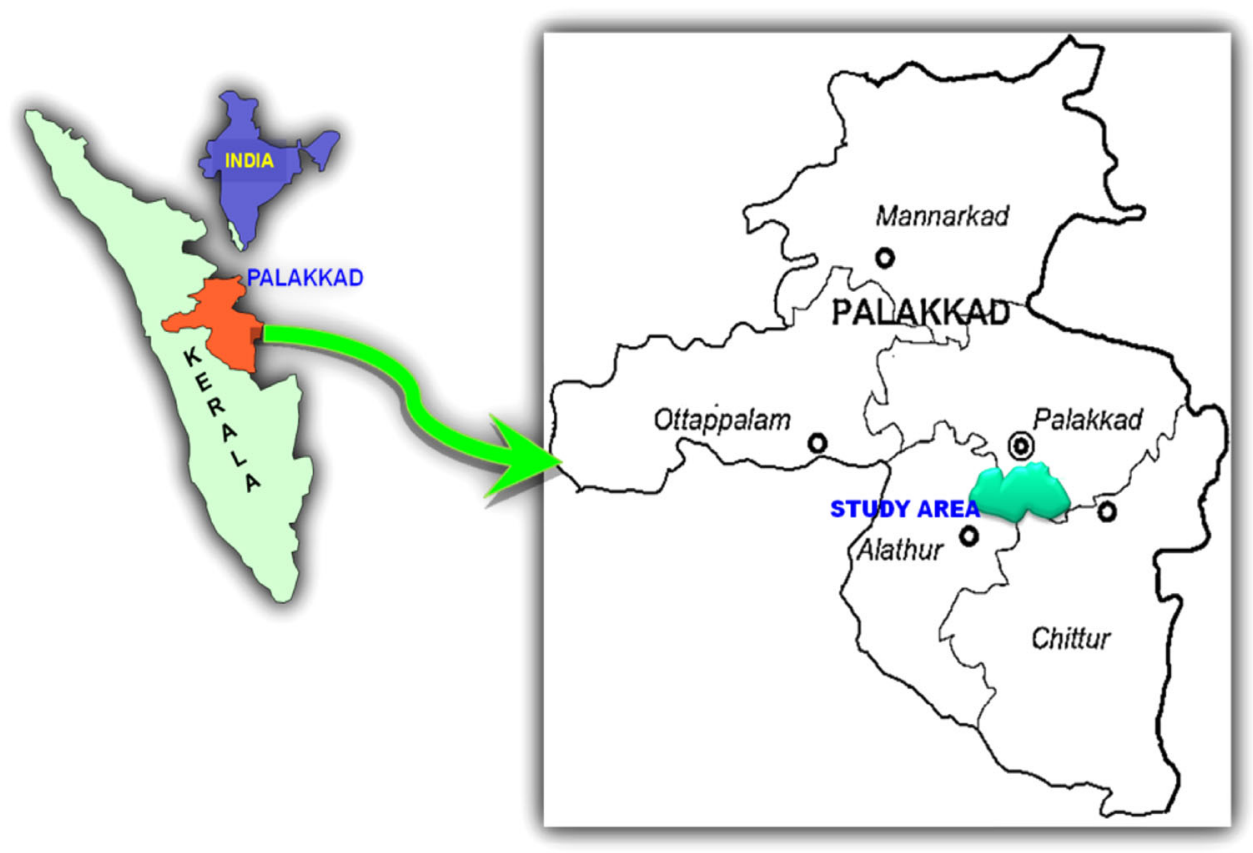


and receive maximum rainfall during the south-west monsoon followed by the north-east monsoon. About $75 \%$ of the annual rain is received from south-west monsoon period during June-September and $25 \%$ rainfall contributes from north-east monsoon. During the period December-May, practically no rain is received. The temperature of the study area ranges from 20 to $45^{\circ} \mathrm{C}$. The maximum temperature recorded at Palakkad is $43{ }^{\circ} \mathrm{C}$. The average annual rainfall of the study is about $2,348 \mathrm{~mm}$.

\section{Geology and hydrology of the study area}

Palakkad district is underlain by Archaean metamorphic rock complex. They include the granulite group, the gneisses, and the schist. Intrusive of pegmatites and quartz veins are also common in the NE part of the district (Soman 1977). The general geologic succession encountered in the study area is given in Table 1 (CGWB 2005). The Archaean crystallines are the major rock types encountered in the study area. This includes Charnockites, khondalites, calc-granulites, hornblende gneiss, migmatites, and gneisses. Half of the study area is covered with the HornblendeBiotite. Gneiss rocks of migmatite complex, having

Table 1 Geological successions of Palakkad District, Kerala (CGWB 2005)

\begin{tabular}{ll}
\hline Age & Lithological units \\
\hline Recent & Top soil, valley fill, and riverine alluvium \\
Subrecent & Laterite \\
Archean & $\begin{array}{l}\text { Pegmatites, quartz vein, dolerite, gabbro, granites, quartz- } \\
\text { mica schist, hornblende biotite, gneiss, ultramafics, } \\
\text { charnockite, and khondalits }\end{array}$ \\
& \\
\hline
\end{tabular}

essential mineral composition of Hornblende and Biotite Proterozoic age pegmatite and quartz vein, which are acidic intrusives, are also common in the NE part of the study area. Hornblende-biotite gneiss rocks are widely distributed in the study area (Fig. 2).

The study area, in general, enjoys a humid tropical climate. Three distinct spells of seasons dominate the area, viz., pre-monsoon, monsoon, and post-monsoon. The rainfall decreases from west towards east of the study area, varying from $2,850.0 \mathrm{~mm}$ at Mannarkkad in the west to $1,757.0 \mathrm{~mm}$ at Chittur near the southeastern part. The annual average rainfall of Palakkad district is 2,106.6 mm (Source IMD, India). Palakkad district receives a total annual rainfall of around 7,348 $\mathrm{mm}$. The rainfall in Palakkad District is not uniform. The variation is so high on the silent valley receives more than $7,000 \mathrm{~mm}$ rainfall whereas eastern part of Attappadi and Chittur receives only a meager $700 \mathrm{~mm}$ rainfall. The major rainfall is received during June to September in the south-west monsoon (71\%). But the north-east monsoon contributes only about $18 \%$. The distribution of rainfall during year 2005-2009 is given in Table 2. District experiences two types of climate with semi-humid climate on the eastern part and humid climate on the western part. (Source:https://sites.google. com/a/iiitmk.ac.in/palakkad/rainfall-and-climate).

As a part the study, well inventory has been carried out for 30 observation wells during post-monsoon (October 2009) and pre-monsoon (April 2010) (Tables 3, 4). The depth to water level measured in monitoring wells during October 2009 varies from 1 to $18 \mathrm{~m}$ (bgl) (Fig. 3a). Hydrology of the study area indicates that periphery of eastern part of study area is having deeper water levels ranging from 3 to $7 \mathrm{~m}$ and towards the western part of study area the water level is ranging from 3 to $16 \mathrm{~m}$, apart
Fig. 2 Geological map of the study area showing groundwater sample locations

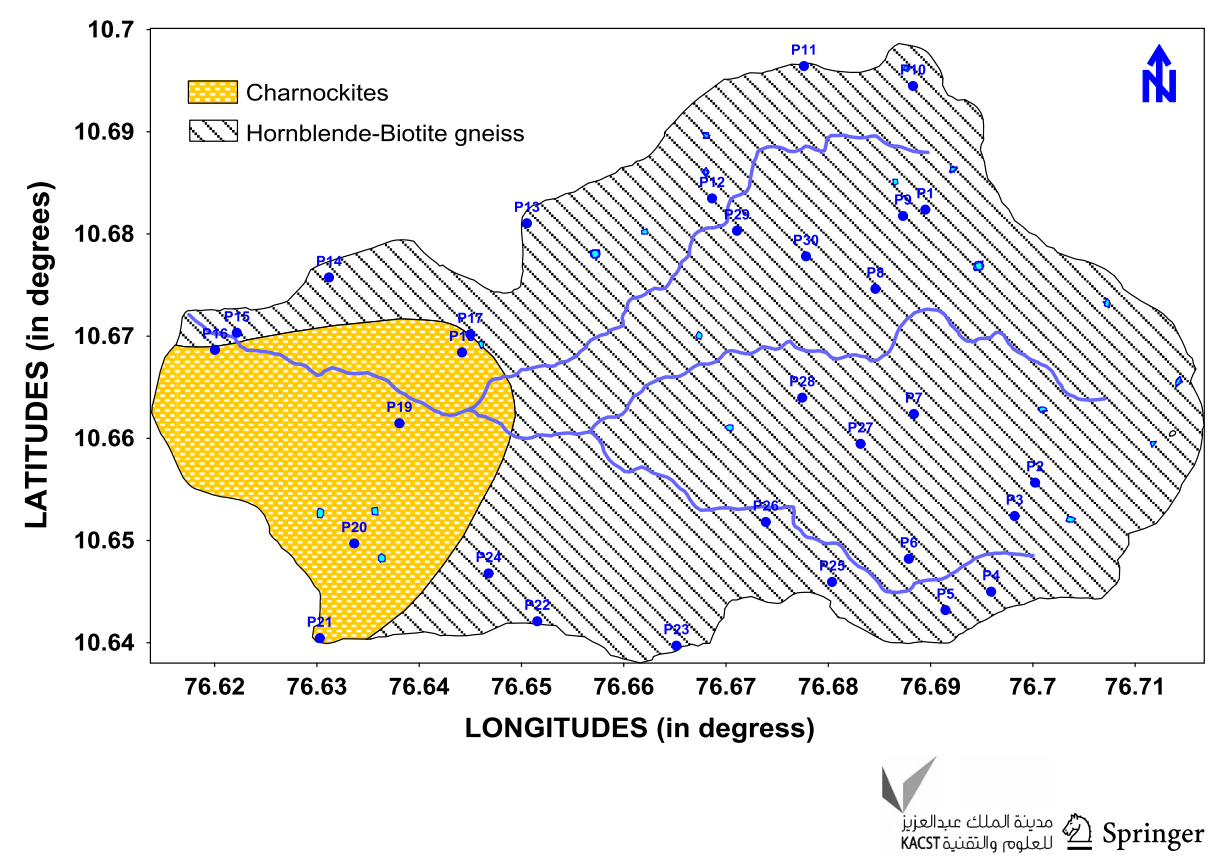


Table 2 Annual and monthly rainfall of Palakkad District for the year 2005-2010

\begin{tabular}{lccrrrrrrrrrrr}
\hline Year/months & Jan & \multicolumn{1}{c}{ Feb } & \multicolumn{1}{c}{ Mar } & \multicolumn{1}{c}{ Apr } & \multicolumn{1}{c}{ May } & June & July & Aug & Sep & Oct & Nov & Dec & Total \\
\hline 2005 & 14.32 & 15.81 & 9.57 & 169.20 & 83.05 & 353.04 & 690.48 & 222.53 & 272.07 & 140.32 & 98.26 & 61.47 & $2,130.12$ \\
2006 & 19.93 & 0 & 95.13 & 69.35 & 297.18 & 385.56 & 406.44 & 293.67 & 193.39 & 217.56 & 157.16 & 0 & $2,135.37$ \\
2007 & 2.25 & 12 & 38.50 & 81.27 & 91.63 & 507.75 & 726.46 & 350.18 & 395.77 & 282.56 & 33.33 & 32 & $2,553.7$ \\
2008 & 10.00 & 33.62 & 141.41 & 31.52 & 27.98 & 298.46 & 289.69 & 170.57 & 171.61 & 352.30 & 21.93 & 2.25 & $1,551.34$ \\
2009 & 0 & 0 & 68.34 & 10.68 & 97.91 & 193.88 & 727.41 & 203.06 & 236.27 & 183.84 & 209.71 & 11.1 & $1,942.2$ \\
2010 & 16.57 & 0 & 24.90 & 136.45 & 81.05 & 317.43 & 387.13 & 211.90 & 203.93 & 253.39 & 220.48 & 12.86 & $1,866.09$ \\
\hline
\end{tabular}

Table 3 Water level and physico-chemical analyses of groundwater samples of study area collected during Post-monsoon (October 2009)

\begin{tabular}{|c|c|c|c|c|c|c|c|c|c|c|c|c|c|c|c|c|}
\hline $\begin{array}{l}\text { Well } \\
\text { no. }\end{array}$ & $\begin{array}{l}\text { WL } \\
(\mathrm{m})\end{array}$ & $\mathrm{EC}$ & $\mathrm{pH}$ & $\begin{array}{l}\text { TDS } \\
(\mathrm{mg} / \mathrm{L})\end{array}$ & $\begin{array}{l}\text { T. Alkl. } \\
\text { (mg/L) }\end{array}$ & $\begin{array}{l}\text { T.H } \\
(\mathrm{mg} / \mathrm{L})\end{array}$ & $\begin{array}{l}\mathrm{CO}_{3} \\
(\mathrm{mg} / \mathrm{L})\end{array}$ & $\begin{array}{l}\mathrm{HCO}_{3} \\
(\mathrm{mg} / \mathrm{L})\end{array}$ & $\begin{array}{l}\mathrm{SO}_{4} \\
(\mathrm{mg} / \mathrm{L})\end{array}$ & $\begin{array}{l}\mathrm{NO}_{3} \\
(\mathrm{mg} / \mathrm{L})\end{array}$ & $\begin{array}{l}\mathrm{Cl} \\
(\mathrm{mg} / \mathrm{L})\end{array}$ & $\begin{array}{l}\mathrm{F} \\
(\mathrm{mg} / \mathrm{L})\end{array}$ & $\begin{array}{l}\mathrm{Ca} \\
(\mathrm{mg} / \mathrm{L})\end{array}$ & $\begin{array}{l}\mathrm{Mg} \\
(\mathrm{mg} / \mathrm{L})\end{array}$ & $\begin{array}{l}\mathrm{Na} \\
(\mathrm{mg} / \mathrm{L})\end{array}$ & $\begin{array}{l}\mathrm{K} \\
(\mathrm{mg} / \mathrm{L})\end{array}$ \\
\hline $\mathrm{P} 1$ & 3.3 & 1,477 & 7.6 & 945 & 310 & 376 & 186 & 310 & 41 & 14 & 227 & 0.8 & 82 & 42 & 60 & 64 \\
\hline $\mathrm{P} 2$ & 7.75 & 776 & 7.3 & 497 & 135 & 272 & 81 & 135 & 12 & 2 & 168 & 0.3 & 46 & 38 & 4.4 & 2.1 \\
\hline P3 & 4.35 & 414 & 7.1 & 265 & 131 & 140 & 79 & 131 & 15 & ND & 44 & 0.4 & 22 & 20 & 28.8 & 1.7 \\
\hline P4 & 3.65 & 879 & 7.8 & 563 & 332 & 232 & 199 & 332 & 23 & 10 & 84 & 0.7 & 53 & 24 & 156 & 5.4 \\
\hline P5 & 3.45 & 1,648 & 7.6 & 1,055 & 183 & 340 & 110 & 183 & 48 & 14.4 & 375 & 0.6 & 78 & 35 & 100 & 2.2 \\
\hline P6 & 1.9 & 1,039 & 7.4 & 665 & 183 & 336 & 110 & 183 & 15 & 0.2 & 239 & 0.4 & 53 & 50 & 27.6 & 3.3 \\
\hline P7 & 3.85 & 1,465 & 7.1 & 938 & 389 & 376 & 233 & 389 & 31 & ND & 255 & 0.6 & 80 & 43 & 92 & 6 \\
\hline P8 & 3.65 & 310 & 6.1 & 198 & 83 & 72 & 50 & 83 & 17 & 10.1 & 32 & 0.2 & 18 & 7 & 36 & 2.6 \\
\hline P9 & 2.95 & 875 & 7.2 & 560 & 227 & 288 & 136 & 227 & 86 & 5.5 & 104 & 0.5 & 61 & 33 & 28.4 & 9 \\
\hline P10 & 2.7 & 2,010 & 7.0 & 1,286 & 362 & 404 & 217 & 362 & 19 & 4 & 510 & 0.8 & 162 & 0 & 76 & 3.4 \\
\hline P11 & 2.35 & 266 & 6.7 & 170 & 92 & 80 & 55 & 92 & 16 & 3.9 & 24 & 0.4 & 13 & 12 & 29.2 & 1.1 \\
\hline P12 & 0.9 & 634 & 7.7 & 406 & 188 & 228 & 113 & 188 & 25 & 4.2 & 84 & 0.5 & 48 & 26 & 40.2 & 6.3 \\
\hline P13 & 2.75 & 1,963 & 6.7 & 1,256 & 114 & 408 & 68 & 114 & 23 & 38.9 & 494 & 0.2 & 72 & 55 & 108 & 5.6 \\
\hline P14 & 16.1 & 630 & 7.7 & 403 & 231 & 252 & 139 & 231 & 32 & ND & 56 & 0.4 & 53 & 29 & 34 & 5.9 \\
\hline P15 & 4.3 & 436 & 7.6 & 279 & 140 & 140 & 84 & 140 & 12 & 4.7 & 48 & 0.5 & 27 & 17 & 33.2 & 6 \\
\hline P16 & 3 & 454 & 7.3 & 291 & 127 & 144 & 76 & 127 & 25 & 2.4 & 52 & 0.4 & 19 & 16 & 37.2 & 1.6 \\
\hline P17 & 1.4 & 242 & 6.6 & 155 & 74 & 40 & 45 & 74 & 10 & 4.7 & 32 & ND & 11 & 3 & 22.8 & 1.7 \\
\hline P19 & 5.53 & 111 & 6.5 & 71 & 48 & 28 & 29 & 48 & 4 & 1.7 & 16 & ND & 5 & 4 & 12 & 1.5 \\
\hline P20 & 2.15 & 638 & 7.6 & 408 & 240 & 288 & 144 & 240 & 17 & 3.2 & 76 & 0.6 & 45 & 43 & 23.6 & 1.4 \\
\hline P21 & 2.27 & 107 & 7.5 & 68 & 52 & 36 & 31 & 52 & 2 & ND & 15 & 0.2 & 8 & 4 & 12 & 0.1 \\
\hline P22 & 2.55 & 836 & 7.1 & 535 & 227 & 212 & 136 & 227 & 34 & 7.76 & 92 & 0.5 & 56 & 17 & 80 & 110 \\
\hline P23 & 3.22 & 412 & 7.4 & 264 & 144 & 140 & 86 & 144 & 19 & ND & 36 & 0.4 & 32 & 15 & 36.8 & 3.3 \\
\hline P24 & 1.65 & 358 & 7.4 & 229 & 122 & 128 & 73 & 122 & 13 & 4.3 & 32 & 0.6 & 20 & 18 & 24.8 & 0.4 \\
\hline P25 & 2.1 & 2,390 & 7.6 & 1,530 & 397 & 1,056 & 238 & 397 & 29 & 1.2 & 734 & 0.6 & 168 & 155 & 72 & 1.1 \\
\hline P26 & 1.01 & 426 & 7.2 & 273 & 192 & 156 & 115 & 192 & 17 & ND & 24 & 0.6 & 38 & 15 & 24 & 2.8 \\
\hline P27 & 2.25 & 811 & 7.2 & 519 & 214 & 168 & 128 & 214 & 33 & 4.5 & 116 & 0.4 & 35 & 19 & 42.4 & 1.5 \\
\hline P28 & 2.35 & 565 & 6.7 & 362 & 131 & 144 & 79 & 131 & 21 & ND & 96 & 0.2 & 29 & 17 & 43.2 & 0.8 \\
\hline P29 & 2.45 & 3,000 & 7.2 & 1,920 & 376 & 744 & 225 & 376 & 81 & 14.8 & 881 & 0.5 & 219 & 48 & 100 & 8.2 \\
\hline P30 & 2.25 & 1,196 & 7.8 & 765 & 210 & 344 & 126 & 210 & 79 & 17.5 & 207 & 0.6 & 53 & 52 & 52 & 5.1 \\
\hline Min & 0.9 & 107 & 6.1 & 68 & 48 & 28 & 29 & 48 & 2 & 0.2 & 15 & 0.2 & 5 & 0 & 4.4 & 0.1 \\
\hline Max & 16.1 & 3,000 & 7.8 & 1,920 & 397 & 1,056 & 238 & 397 & 86 & 38.9 & 881 & 0.8 & 219 & 155 & 156 & 110 \\
\hline Ave & 3.38 & 951 & 7.23 & 581.93 & 194.96 & 261.10 & 116.93 & 194.96 & 27.55 & 7.90 & 177.68 & 0.47 & 55.37 & 29.55 & 49.53 & 9.10 \\
\hline SD & 2.80 & 792 & 0.42 & 460.60 & 101.97 & 214.59 & 61.06 & 101.97 & 21.43 & 8.49 & 220.93 & 0.16 & 49.86 & 28.93 & 35.03 & 22.55 \\
\hline
\end{tabular}

T. Alkl total alklanity, T.H total hardness, Min minimum, Max maximum, Ave average, SD standard deviation 
Table 4 Water level and physico-chemical analyses of groundwater samples of study area collected during Pre-monsoon (April 2010)

\begin{tabular}{|c|c|c|c|c|c|c|c|c|c|c|c|c|c|c|c|c|}
\hline $\begin{array}{l}\text { Well } \\
\text { no. }\end{array}$ & $\begin{array}{l}\text { WL } \\
(\mathrm{m})\end{array}$ & EC & $\mathrm{pH}$ & $\begin{array}{l}\text { TDS } \\
(\mathrm{mg} / \mathrm{L})\end{array}$ & $\begin{array}{l}\text { T. Alkal } \\
(\mathrm{mg} / \mathrm{L})\end{array}$ & $\begin{array}{l}\text { T.H } \\
(\mathrm{mg} / \mathrm{L})\end{array}$ & $\begin{array}{l}\mathrm{CO}_{3} \\
(\mathrm{mg} / \mathrm{L})\end{array}$ & $\begin{array}{l}\mathrm{HCO}_{3} \\
(\mathrm{mg} / \mathrm{L})\end{array}$ & $\begin{array}{l}\mathrm{SO}_{4} \\
(\mathrm{mg} / \mathrm{L})\end{array}$ & $\begin{array}{l}\mathrm{NO}_{3} \\
(\mathrm{mg} / \mathrm{L})\end{array}$ & $\begin{array}{l}\mathrm{Cl} \\
(\mathrm{mg} / \mathrm{L})\end{array}$ & $\begin{array}{l}\mathrm{F} \\
(\mathrm{mg} / \mathrm{L})\end{array}$ & $\begin{array}{l}\mathrm{Ca} \\
(\mathrm{mg} / \mathrm{L})\end{array}$ & $\begin{array}{l}\mathrm{Mg} \\
(\mathrm{mg} / \mathrm{L})\end{array}$ & $\begin{array}{l}\mathrm{Na} \\
(\mathrm{mg} / \mathrm{L})\end{array}$ & $\begin{array}{l}\mathrm{K} \\
(\mathrm{mg} / \mathrm{L})\end{array}$ \\
\hline P1 & 5.95 & 1,483 & 7.7 & 949 & 339 & 372 & 204 & 339.2 & 57 & 7 & 228 & 1.2 & 91 & 35 & 188 & 44 \\
\hline P2 & NA & 969 & 6.9 & 620 & 161 & 316 & 97 & 161.12 & 16 & 5 & 140 & 0.6 & 56 & 43 & 68 & 2 \\
\hline P3 & 4.93 & 468 & 6.6 & 300 & 127 & 140 & 76 & 127.2 & 13 & 1 & 192 & 0.6 & 24 & 19 & 32 & 1 \\
\hline P4 & 5.40 & 496 & 7.0 & 317 & 110 & 144 & 66 & 110.24 & 11 & 2 & 52 & 0.7 & 30 & 17 & 32 & 1 \\
\hline P5 & 3.27 & 1,273 & 7.0 & 815 & 225 & 248 & 135 & 224.72 & 23 & 4 & 108 & 1.0 & 43 & 34 & 78 & 1 \\
\hline P6 & 2.65 & 871 & 6.7 & 557 & 157 & 268 & 94 & 156.88 & 15 & 1 & 220 & 0.6 & 67 & 24 & 58 & 3 \\
\hline P7 & 4.75 & 1,491 & 6.7 & 954 & 343 & 328 & 206 & 343.44 & 32 & 1 & 384 & 1.0 & 80 & 31 & 174 & 2 \\
\hline P8 & 6.60 & 470 & 6.6 & 301 & 123 & 80 & 74 & 122.96 & 23 & 1 & 240 & 0.7 & 18 & 9 & 68 & 1 \\
\hline P9 & 5.07 & 1,025 & 7.1 & 656 & 212 & 300 & 127 & 212 & 92 & 3 & 120 & 0.9 & 61 & 36 & 110 & 3 \\
\hline P10 & 4.20 & 815 & 7.1 & 522 & 191 & 160 & 114 & 190.8 & 12 & 1 & 128 & 1.5 & 32 & 19 & 102 & 1 \\
\hline P11 & 4.26 & 397 & 7.0 & 254 & 98 & 80 & 59 & 97.52 & 18 & 2 & 44 & 1.3 & 16 & 10 & 38 & 0 \\
\hline P12 & 2.30 & 859 & 7.3 & 550 & 195 & 280 & 117 & 195.04 & 1 & 1 & 120 & 0.6 & 59 & 32 & 46 & 2 \\
\hline P13 & 5.10 & 1,917 & 7.0 & 1,227 & 187 & 272 & 112 & 186.56 & 32 & 25 & 412 & 0.7 & 72 & 22 & 312 & 1 \\
\hline P14 & NA & 734 & 7.6 & 470 & 208 & 256 & 125 & 207.76 & 40 & 1 & 52 & 0.5 & 62 & 24 & 24 & 2 \\
\hline P15 & 4.28 & 508 & 7.7 & 325 & 136 & 136 & 81 & 135.68 & 11 & 0 & 64 & 0.6 & 29 & 16 & 40 & 3 \\
\hline P16 & 5.14 & 720 & 8.1 & 461 & 195 & 240 & 117 & 195.04 & 75 & 1 & 52 & 1.1 & 67 & 17 & 40 & 2 \\
\hline P17 & 2.30 & 243 & 6.9 & 156 & 68 & 56 & 41 & 67.84 & 9 & 1 & 36 & 0.2 & 14 & 5 & 26 & 1 \\
\hline P19 & NA & 446 & 7.1 & 285 & 157 & 140 & 94 & 156.88 & 9 & 1 & 44 & 0.7 & 42 & 9 & 25 & 1 \\
\hline P20 & 2.45 & 540 & 7.1 & 346 & 165 & 196 & 99 & 165.36 & 24 & 1 & 48 & 1.0 & 32 & 28 & 19 & 1 \\
\hline P21 & 3.72 & 178 & 6.7 & 114 & 85 & 64 & 51 & 84.8 & 15 & 1 & 12 & 0.5 & 14 & 7 & 11 & 0 \\
\hline $\mathrm{P} 22$ & 7.10 & 810 & 7.3 & 518 & 170 & 184 & 102 & 169.6 & 2 & 6 & 96 & 0.6 & 50 & 15 & 74 & 49 \\
\hline $\mathrm{P} 23$ & NA & 439 & 7.6 & 281 & 157 & 136 & 94 & 156.88 & 14 & 1 & 67 & 0.8 & 27 & 17 & 34 & 2 \\
\hline $\mathrm{P} 24$ & 2.27 & 361 & 6.9 & 231 & 119 & 116 & 71 & 118.72 & 10 & 1 & 28 & 0.8 & 24 & 14 & 20 & 1 \\
\hline P25 & 2.85 & 480 & 6.9 & 307 & 144 & 164 & 86 & 144.16 & 15 & 0 & 36 & 0.6 & 37 & 17 & 25 & 1 \\
\hline P26 & NA & 490 & 7.1 & 314 & 178 & 172 & 107 & 178.08 & 17 & 0 & 24 & 1.0 & 45 & 15 & 23 & 4 \\
\hline P27 & 4.56 & 876 & 7.1 & 561 & 216 & 180 & 130 & 216.24 & 34 & 0 & 116 & 0.9 & 34 & 23 & 112 & 2 \\
\hline P28 & 4.63 & 769 & 7.1 & 492 & 178 & 192 & 107 & 178.08 & 11 & 0 & 112 & 0.4 & 48 & 18 & 68 & 2 \\
\hline P29 & 4.05 & 3,380 & 6.9 & 2,163 & 394 & 904 & 237 & 394.32 & 52 & 2 & 1,119 & 0.4 & 310 & 31 & 388 & 3 \\
\hline P30 & 4.05 & 983 & 7.3 & 629 & 191 & 224 & 114 & 190.8 & 42 & 1 & 132 & 1.0 & 35 & 33 & 100 & 6 \\
\hline Min & 4.05 & 178 & 6.9 & 492 & 178 & 180 & 107 & 178.08 & 11 & 0 & 112 & 0.4 & 34 & 18 & 68 & 2 \\
\hline $\operatorname{Max}$ & 4.63 & 3,380 & 7.3 & 2,163 & 394 & 904 & 237 & 394.32 & 52 & 25 & 1,119 & 1 & 310 & 33 & 388 & 6 \\
\hline Ave & 4.32 & 904 & 7.10 & 961.25 & 244.75 & 375.0 & 147.0 & 244.86 & 34.75 & 0.75 & 369.75 & 0.68 & 106.75 & 26.25 & 167.0 & 3.25 \\
\hline SD & 1.34 & 759 & 0.36 & 403.35 & 73.68 & 155.44 & 44.35 & 73.79 & 21.38 & 4.68 & 210.85 & 0.29 & 53.58 & 9.81 & 87.26 & 11.61 \\
\hline
\end{tabular}

T. Alkl total alklanity, T.H total hardness, Min minimum, Max maximum, Ave average, SD standard deviation

from that middle part of the area is having a shallow water level of 1-3 m. In pre-monsoon (April 2010), the water level varies from 2 to $8 \mathrm{~m}$ below ground level (Fig. 3b). The water level above mean sea level varies from 64 to $116 \mathrm{~m}$ which follows topographic trend. The elevation is gradually increasing from west to east and the flow direction is from east towards the west of study area. According to the pumping test survey which has been carried out in few locations of the study area, the transmissivity values which ranged from 38.5 to $176 \mathrm{~m}^{2} /$ day and, hydraulic conductivity values ranged from 8.22 to $176 \mathrm{~m} /$ day.

\section{Materials and methods}

In order to assess the physico-chemical parameters, a total of 30 shallow groundwater (dug wells) samples were collected covering the Pudunagaram area, Palakkad District, Kerala, have been selected (Fig. 2). The water samples were collected for post-monsoon (October, 2009) and premonsoon (April, 2010) seasons with in situ measurement of $\mathrm{pH}$ and EC. Water samples were collected in a plastic container of 1-L capacity for detailed chemical analysis from all observation dug wells. These containers were washed thoroughly with distilled water and dried before 
Fig. 3 a, b Variation of depth to the water level (bgl) for postmonsoon (October 2009) and pre-monsoon (April 2010) in the study area
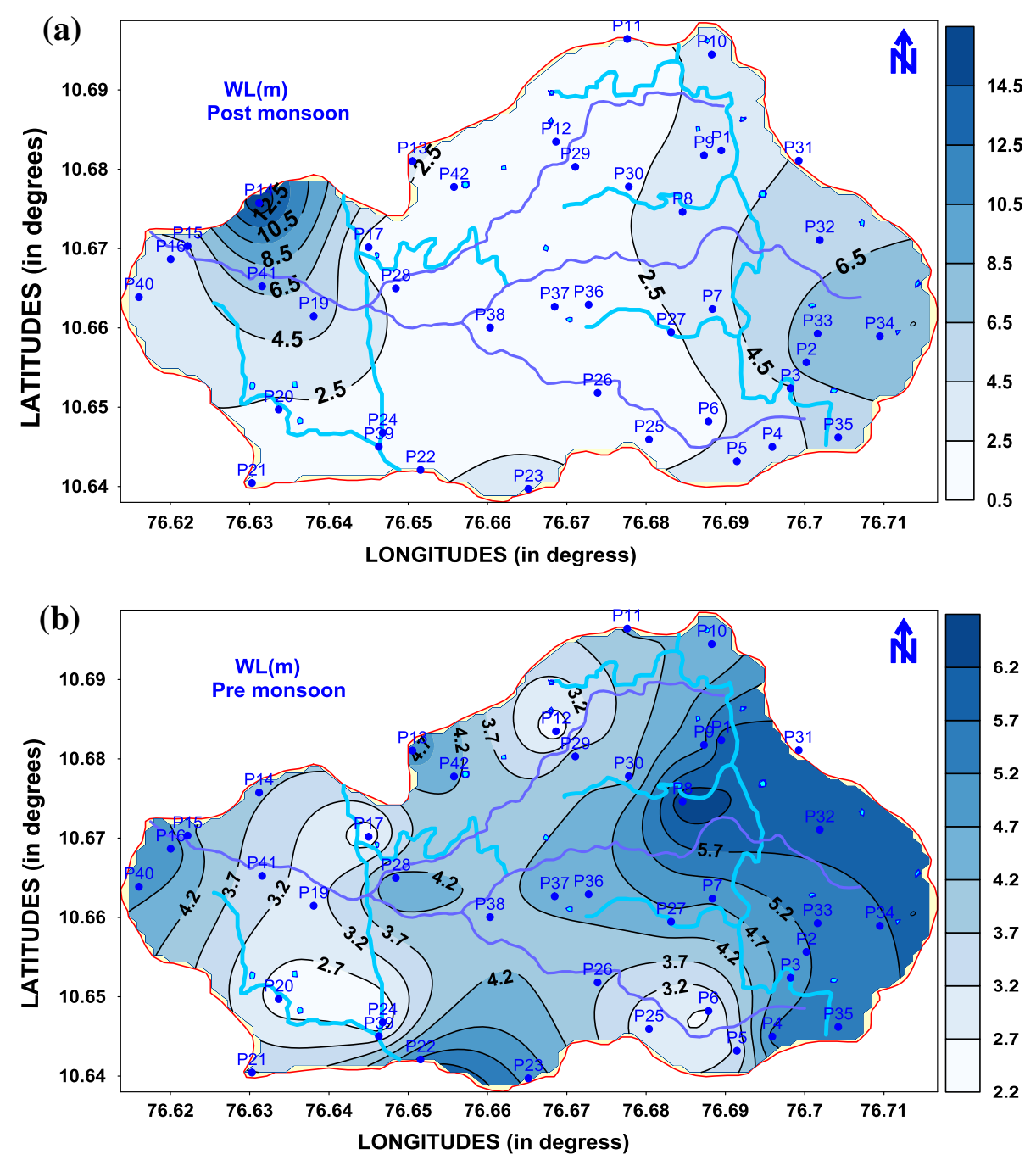

being filled with water samples. The containers were numbered serially along with a proper record of well/ sample location, date, static water level, and prior to the sampling. Groundwater samples were collected after the well was subjected to pumping for at least 5-10 min to obtain the composite sample. The $\mathrm{pH}$ and $\mathrm{EC}$ of the groundwater of the wells were measured by using $\mathrm{HACH}$ HQ40d and its in situ values are recorded. The samples were collected and stored below $4{ }^{\circ} \mathrm{C}$ and analyzed in the Centre for Water Resources Development and Management (CWRDM) Calicut, Kerala. Total dissolved solids (TDS) were calculated from EC with cation factor of multiple 0.64 (Brown et al. 1970). Water samples collected in the field were analyzed for chemical constituents, such as Total dissolved solids (TDS), Total hardness (TH), Calcium (Ca), Magnesium (Mg), Total alkalinity (TA), Carbonates $\left(\mathrm{CO}_{3}\right)$, Bicarbonates $\left(\mathrm{HCO}_{3}\right)$, Sodium $(\mathrm{Na})$, Potassium (K), Chloride $(\mathrm{Cl})$, Nitrate $\left(\mathrm{NO}_{3}\right)$, and Sulfates $\left(\mathrm{SO}_{4}\right)$, were analyzed following the standard procedure of (APHA 1995). The analytical results were evaluated in detail and compared with water quality guidelines of WHO (1984). A brief description of the physico-chemical attributes of groundwater is discussed. $\mathrm{EC}, \mathrm{pH}$, chloride $\left(\mathrm{Cl}^{-}\right)$, fluoride $\left(\mathrm{F}^{-}\right)$, and nitrate $\left(\mathrm{NO}_{3}{ }^{-}\right)$were analyzed using multiple parameters ion meter model Thermo Orion 5 Star. Sulfate $\left(\mathrm{SO}_{4}^{-2}\right)$ was measured using a double beam UV-Vis spectrophotometer model Perkin Elmer Lambda 35 by turbid-metric, stannous chloride, and molybdosilicate, respectively. Sodium $\left(\mathrm{Na}^{+}\right)$, potassium $\left(\mathrm{K}^{+}\right)$, calcium $\left(\mathrm{Ca}^{+2}\right)$, and magnesium $\left(\mathrm{Mg}^{+2}\right)$ were analyzed using flame photometer model CL-378 (Elico, India). Total hardness was determined by EDTA titrimetric method. TDS was measured gravimetrically. Total carbonate and bicarbonate alkalinities were measured by acid-base titration.

\section{Result and discussion}

The analytical results of physical and chemical parameters of the groundwater of the present study are shown in 
Fig. 4 a, b Variation of $\mathrm{pH}$ for post-monsoon (October 2009) and pre-monsoon (April 2010) in the study area
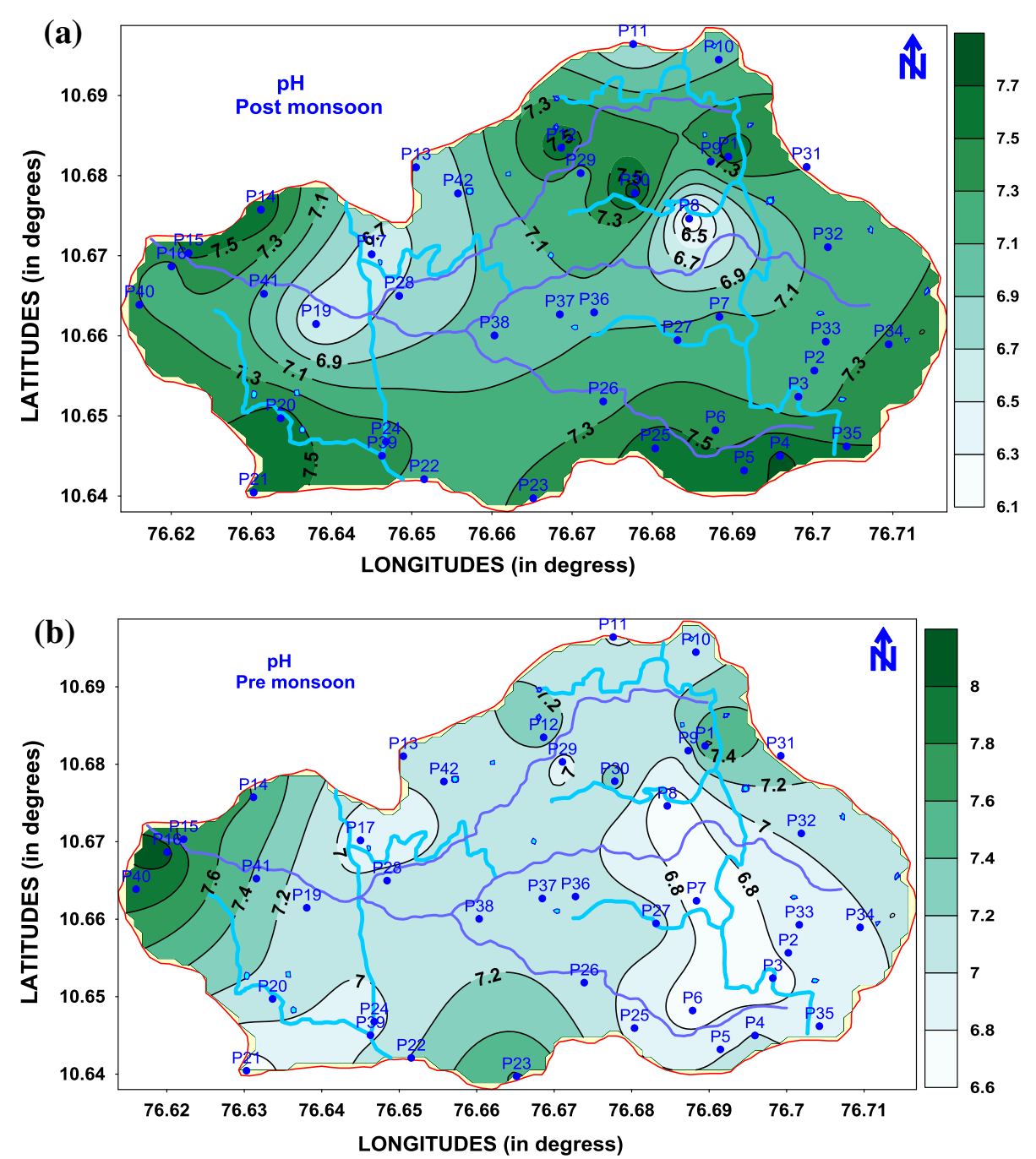

(Tables 3, 4). These were compared with the standard guideline values as recommended by the WHO for drinking and public health purposes. The water levels in the study area are very shallow ranging from $3.38 \mathrm{~m}$ in postmonsoon to $4.25 \mathrm{~m}$ in pre-monsoon as mentioned in (Tables 3, 4). The fluctuation of water level from postmonsoon to pre-monsoon is very low; the effect on TDS concentration is also very low. A brief description of the important physico-chemical attributes of groundwater are discussed.

\section{Hydrogen ion $(\mathrm{pH})$}

The seasonal average of $\mathrm{pH}$ shows a neutral value of 7.15. In post-monsoon, $\mathrm{pH}$ value ranging from 7.0 to 7.5 is covering major area from western part of study area towards the eastern side. The value with 7.4-7.6 is covered at the peripheral of study area. In pre-monsoon, $\mathrm{pH}$ value ranging from 6.6 to 8.1 in major part from west towards east has been covered with a range of 7.0-7.3 as in (Fig. 4a, b). A patch in the south-east part of study area is ranging from 6.6 to 7.0. This low value of $\mathrm{pH}$ is to some extent the influences of fertilizers like ammonium sulfate and super phosphate in agriculture (Appelo and Postma 2005).

Total dissolved solids (TDS)

The value of TDS plays a vital role in the groundwater whether the water is potable or for domestic use. The samples are falling well within the permissible limits (500-2,000 mg/L). The pre-monsoon samples of $44 \%$ and in post-monsoon samples of $44 \%$ are exceeding the limits (Table 5). EC is directly related to TDS, the locations showing high contents of EC support higher TDS concentration. The variation of TDS for post-monsoon and pre-monsoon is shown in (Fig. 5a, b). The major source for TDS is due to livestock waste, landfills and dissolved minerals, and iron and manganese. 
Table 5 Quality of groundwater samples from Palakkad study area for drinking purpose (BIS standards)

\begin{tabular}{|c|c|c|c|c|c|}
\hline \multirow[t]{2}{*}{ Parameter } & \multirow[t]{2}{*}{$\begin{array}{l}\text { Desirable } \\
\text { limit }\end{array}$} & \multicolumn{2}{|c|}{$\begin{array}{l}\text { Post-monsoon } \\
\text { samples }(\%)\end{array}$} & \multicolumn{2}{|c|}{$\begin{array}{l}\text { Pre-monsoon } \\
\text { samples }(\%)\end{array}$} \\
\hline & & $\begin{array}{l}\text { Within } \\
\text { limits }\end{array}$ & $\begin{array}{l}\text { Exceed } \\
\text { limits }\end{array}$ & $\begin{array}{l}\text { Within } \\
\text { limits }\end{array}$ & $\begin{array}{l}\text { Exceed } \\
\text { limits }\end{array}$ \\
\hline $\mathrm{pH}$ & $6.5-8.5$ & 100 & - & 100 & - \\
\hline $\mathrm{EC}$ & $300(\mu \mathrm{mhos} / \mathrm{cm})$ & 13.7 & 86.3 & 3.4 & 96.6 \\
\hline TDS & $500(\mathrm{mg} / \mathrm{L})$ & 55.2 & 44.8 & 55.2 & 44.8 \\
\hline $\begin{array}{l}\text { Total } \\
\text { alkalinity }\end{array}$ & $200(\mathrm{mg} / \mathrm{L})$ & 58.6 & 41.4 & 75.8 & 24.2 \\
\hline $\begin{array}{l}\text { Total } \\
\text { hardness }\end{array}$ & $200(\mathrm{mg} / \mathrm{L})$ & 44.8 & 55.2 & 58.6 & 41.4 \\
\hline $\mathrm{So}_{4}$ & $200(\mathrm{mg} / \mathrm{L})$ & 100 & - & 100 & - \\
\hline $\mathrm{No}_{3}$ & $45(\mathrm{mg} / \mathrm{L})$ & 100 & - & 100 & - \\
\hline $\mathrm{Cl}$ & $250(\mathrm{mg} / \mathrm{L})$ & 79.3 & 20.7 & 89.6 & 10.4 \\
\hline $\mathrm{F}$ & $1.0(\mathrm{mg} / \mathrm{L})$ & 100 & - & 86.2 & 13.8 \\
\hline $\mathrm{Ca}$ & 75 (mg/L) & 79.3 & 20.7 & 86.7 & 10.3 \\
\hline $\mathrm{Mg}$ & $30(\mathrm{mg} / \mathrm{L})$ & 38 & 62 & 72 & 28 \\
\hline $\mathrm{Na}$ & $200(\mathrm{mg} / \mathrm{L})$ & 100 & - & 93.1 & 6.9 \\
\hline
\end{tabular}

Electrical conductivity (EC)

The EC values in post-monsoon are ranging from 107 to $3,000 \mu \mathrm{s} / \mathrm{cm}$ and as so in pre-monsoon from 178 to $3,380 \mu \mathrm{s} / \mathrm{cm}$. The average EC value in post-monsoon is $909.3 \mu \mathrm{s} / \mathrm{cm}$ and pre-monsoon value is $844.5 \mu \mathrm{s} / \mathrm{cm}$. The EC values in pre-monsoon shown $93 \%$ of wells out of limit and in post-monsoon $86 \%$ of wells are out of limits as there are some anthropogenic activities been carried out. The higher value of EC is observed in observation well No. 29 , which is located close to a stream along the road, in Pudunagaram village showing its limits more than 3,000 in both monsoon seasons.

\section{Total alkalinity}

Total alkalinity is the measure of the capacity of water to neutralize a strong acid. The major source for alkalinity is due to landfills and pipe lines. The permissible limit of alkalinity is $200 \mathrm{mg} / \mathrm{L}$. In pre-monsoon, $24 \%$ of samples are out of limits, and in the post-monsoon, $41 \%$ of samples are out of limits (Table 5). The value of alkalinity is $60 \mathrm{mg} / \mathrm{L}$ indicating hard water, which makes the fresh water unpalatable (Fig. 6a, b)

Total hardness $(\mathrm{TH})$

Total hardness value is between 150 and $300 \mathrm{mg} / \mathrm{L}$ means the water is hard and the value $>300 \mathrm{mg} / \mathrm{L}$ means it is very hard (Todd 2001). The pre-monsoon samples of $31 \%$ are out of limits, and in post-monsoon, $17 \%$ of samples are out of limits (Table 5). The major source for hardness is due to calcium and magnesium in the soil and aquifer minerals. High concentration of TH in water may cause kidney stone and heart disease in human. The maximum permissible limits of water quality for drinking as given by BIS (1991) and WHO (1993) is $600 \mathrm{mg} / \mathrm{L}$ (Fig. 7a, b).

Nitrate

Nitrate in the study area is found to be comparatively very low in concentration. However, the season wise averages show slightly higher values during post-monsoon. The peak values registered during pre-monsoon and postmonsoon are 25.1 and $38.9 \mathrm{mg} / \mathrm{L}$, respectively, and all of the samples are within the permissible limit. Being loosely bound to soils, nitrate is expected to be more in runoff and hence its concentration increases during rainy seasons (Rao et al. 2004).

\section{Calcium and magnesium}

Among the cations, $\mathrm{Ca}$ content shows seasonal variation and majority of the samples in all the seasons fall within the permissible limit $(75 \mathrm{mg} / \mathrm{L})$. Among the total samples, $20.6 \%$ in post-monsoon and $68.9 \%$ in pre-monsoon seasons register values beyond the permissible limit. The content of Ca spreads between 5 and $219 \mathrm{mg} / \mathrm{L}$, and 20 to $776 \mathrm{mg} / \mathrm{L}$ averaging 55 and $144.6 \mathrm{mg} / \mathrm{L}$ during postmonsoon and pre-monsoon, respectively. The content up to $1,800 \mathrm{mg} / \mathrm{L}$ does not impair any physiological reaction in man (Lehr et al. 1980). High concentration of $\mathrm{Ca}$ is not desirable in washing, laundering, and bathing. Although the sources of $\mathrm{Ca}$ in groundwater resources are mainly the crystalline limestone associated with khondalitic rocks, the prolonged agricultural activities prevailing in the study area may also directly or indirectly augment the mineral dissolution in groundwater (Bohlke 2002). The content of $\mathrm{Mg}$ is comparatively less than that of $\mathrm{Ca}$. The $\mathrm{Mg}$ exhibits gradual increase in concentration from post-monsoon to pre-monsoon seasons. Of the total samples, $10.34 \%$ in post-monsoon, show concentrations outside the permissible limit. The geochemistry of the rock types may have an influence in the concentration of $\mathrm{Mg}$ in groundwater.

\section{Sodium and potassium}

$\mathrm{Na}$ is one of the important naturally occurring cations and its concentration in fresh waters is generally lower than that of $\mathrm{Ca}$ and $\mathrm{Mg}$. But in the present investigation, the average concentration of $\mathrm{Na}$ is comparatively higher than that of $\mathrm{Ca}$ and Mg. Previous studies (CGWB 2005) in the same area 
Fig. 5 a, b Variation of total dissolved solids (TDS) for postmonsoon (October 2009) and pre-monsoon (April 2010) in the study area
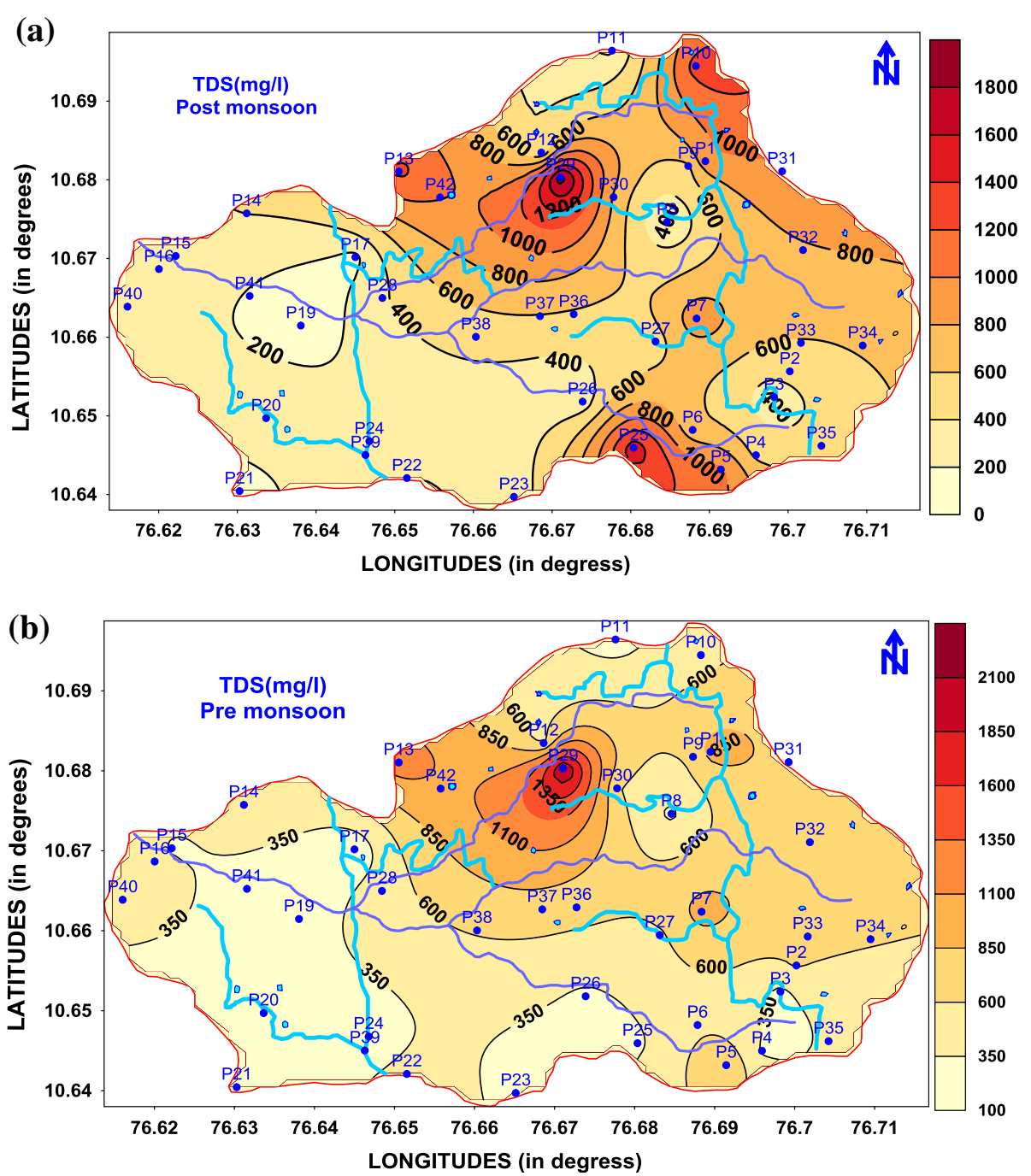

also corroborate these results. For aesthetic reason, the guideline value given by WHO is $200 \mathrm{mg} / \mathrm{L}$. Comparatively higher values were recorded in pre-monsoon with the values range between 10.8 and $388 \mathrm{mg} / \mathrm{L}$ and 4.4 and $156 \mathrm{mg} / \mathrm{L}$ in post-monsoon with the averages of 88.2 and $51.5 \mathrm{mg} / \mathrm{L}$, respectively. Sample No. 29 in pre-monsoon registered value above the permissible limit. Since the eastern parts are covered mainly by hornblende-biotite gneiss and are migmatised, the geological influence on the concentration of the cations is well understood (Soman 1977). The concentration of $\mathrm{K}$ shows very low values in all the seasons with the averages of 6.1 in pre-monsoon and $12 \mathrm{mg} / \mathrm{L}$ post-monsoon. Though, most of the source rocks contain approximately equal amounts of $\mathrm{Na}$ and $\mathrm{K}$, and both are released during weathering, a part of the $\mathrm{K}$ go into clay structure and thereby its concentration gets reduced in water. However, sample Nos. 1 and 22 throughout the study period, 44 and 48.5 in pre-monsoon and 64 and 110 in post-monsoon registered values above the drinking water standard of $12 \mathrm{mg} / \mathrm{L}$ (Griffioen 2001; WHO 1993). Potassium contamination in groundwater can result from the application of inorganic fertilizer at greater than agronomic rates. Loss of nutrients, including $\mathrm{K}$, from agricultural land have been identified as one of the main causative factors in reducing water quality in many parts of arid and semi-arid regions (WHO 1993; Jalali 2005; Kolahchi and Jalali 2006).

Chloride $(\mathrm{Cl})$

The principal sources of chloride are animal organic matter, sewage from drainages and refuse. The usage of huge fertilizer for paddy cultivation also plays a vital role as the source of chloride. The maximum permissible limit for $\mathrm{Cl}$ in drinking water is $250-1,000 \mathrm{mg} / \mathrm{L}$ (WHO 1993). In the pre-monsoon, $10 \%$ of samples are out of limits, and in the post-monsoon, $20 \%$ of samples are out of limits as in (Fig. 8a, b) and Table 5. 
Fig. 6 a, b Variation of total alkalinity for post-monsoon (October 2009) and premonsoon (April 2010) in the study area
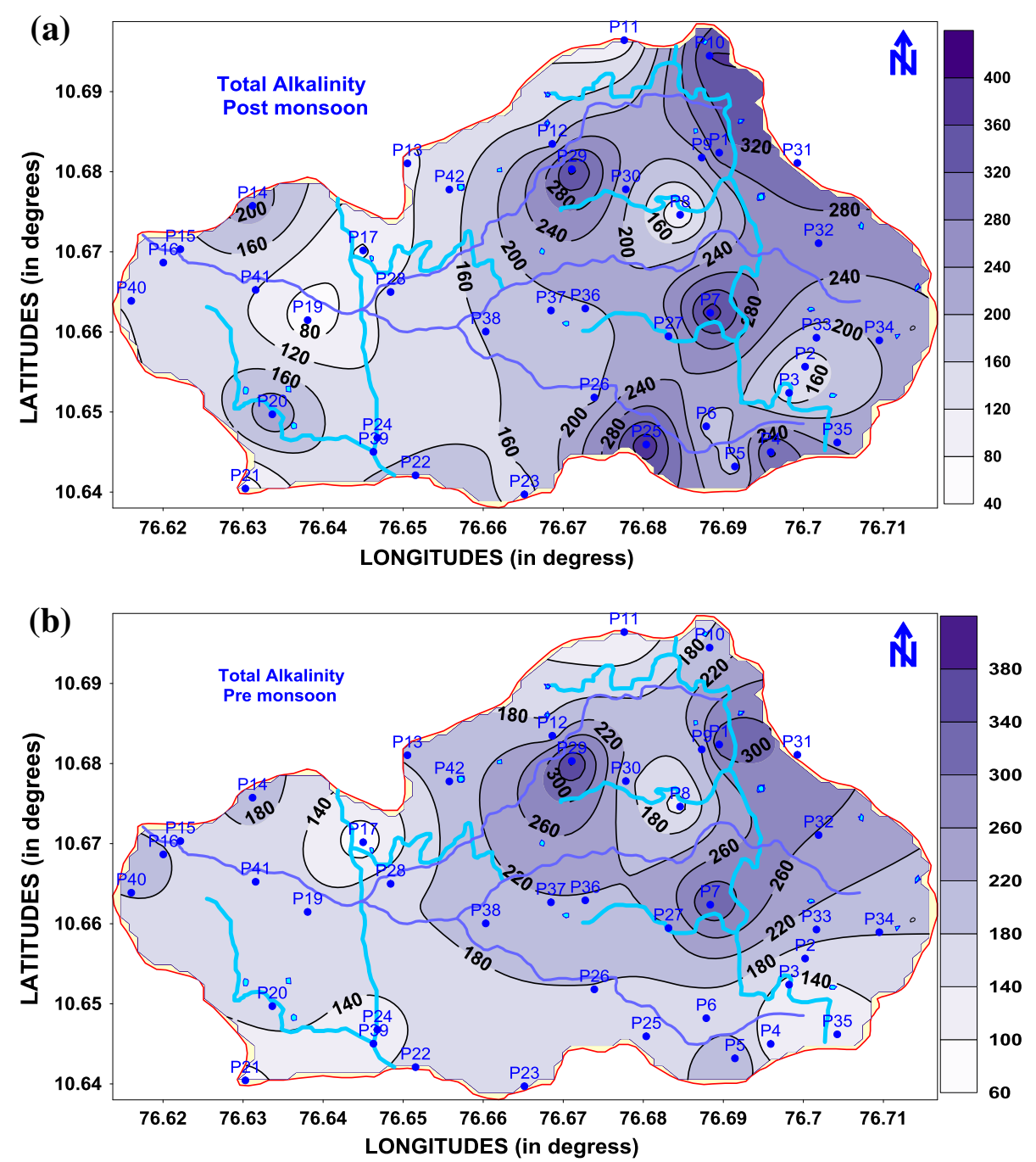

\section{Water quality criteria for irrigation}

Water quality for irrigation refers to its suitability for agricultural use. The concentration and composition of dissolved constituents in water can be determined to know its quality for irrigation use. Quality of water is an important consideration in any appraisal of salinity or alkalinity conditions in an irrigated area. Good quality of water (good soil and water management practices) can promote maximum crop yield. The suitability of water for irrigation depends upon TDS (salinity) and the sodium content in relation to the amounts of calcium and magnesium or SAR (Alagbe 2006). The suitability of groundwater for irrigation use was evaluated by calculating salinity (EC), sodium absorption ratio (SAR), Kelly's ratio (KR), residual sodium carbonate (RSC), soluble sodium percentage (SSP), permeability index (PI), and water quality index (WQI).
Classification of groundwater on salinity (EC)

Salinization is one of the most prolific adverse environmental impacts associated with irrigation. Saline condition severely limits the choice of crop, adversely affect crop germination and yields and can make soils difficult to work. Excessive solutes in irrigation water are a common problem in semi-arid areas where water loss through evaporation is maximum. Salinity problem encountered in irrigated agriculture are most likely to arise where drainage is poor. This allows the water table to rise close to the root zone of plants, causing the accumulation of sodium salts in the soil solution through capillary rise following surface evaporation of water. The higher the EC, the less suitable is water available to plants, because plants can only transpire "pure" water and usable plant water in the soil solution decreases dramatically as EC increases. The amount of water 
Fig. 7 a, b Variation of total hardness (TH) for post-monsoon (October 2009) and premonsoon (April 2010) in the study area
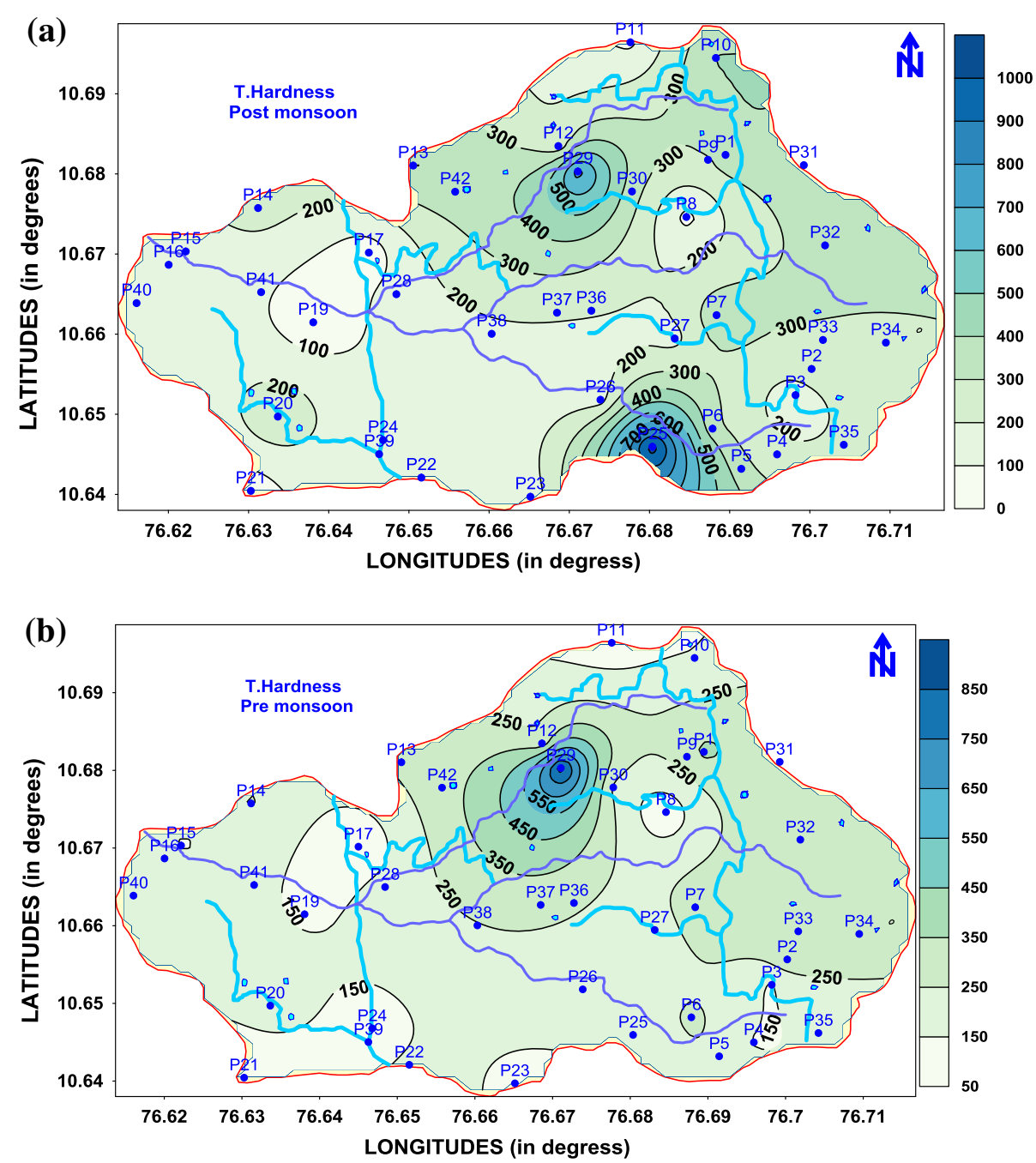

transpired through a crop is directly related to yield; therefore, irrigation water with high EC reduces yield potential. The electrical conductivity (EC) of the groundwater in the study area varies from 178 to $3,380 \mu \mathrm{S} / \mathrm{cm}$ and $107-3,000 \mu \mathrm{S} / \mathrm{cm}$ in pre-monsoon and post-monsoon, respectively (Tables 3,4 ). Based on the $\mathrm{EC}$, the groundwater of study area has been classified into four classes (Handa 1969) (Table 6). The total concentration of soluble salts in irrigation water can be expressed as low $(E C=<250 \mu \mathrm{S} / \mathrm{cm})$, medium $(250-750 \mu \mathrm{S} /$ $\mathrm{cm})$, high $(750-2,250 \mu \mathrm{S} / \mathrm{cm})$, and very high $(>2,250 \mu \mathrm{S} /$ $\mathrm{cm}$ ); and classified as C1, C2, C3 and C4 salinity zones, respectively (Richards 1954; Singh et al. 2011). While a high salt concentration (high EC) in water leads to formation of saline soil and a high sodium concentration leads to development of an alkaline soil.

In Wilcox diagram (Fig. 9), the EC is taken as salinity hazard and SAR as alkalinity hazard, shows low alkalinity hazard (S1) and Medium-high salinity hazard (C2-C3) for majority of groundwater samples from both seasons.
However, two samples from post-monsoon (P25 and P29) fall in $\mathrm{S} 1-\mathrm{C} 4$, while a sample from pre-monsoon (P28) falls in S2-C4 and a sample (P14) from pre-monsoon falls in S2-C3, which represent medium alkalinity hazard and high to very high salinity (C3-C4). It seems that there is a gradual increase in both alkalinity and salinity characters from the groundwater samples during pre- to post-monsoon periods due to long-term precipitation and water-rock interaction in space and time.

Sodium adsorption ratio (SAR)

The sodium/alkali hazard is typically expressed as the sodium adsorption ratio (SAR). Sodium concentration is important in classifying the water for irrigation purposes because sodium concentration can reduce the soil permeability and soil structure (Todd 1980; Domenico and Schwartz 1990). The sodium adsorption ratio values for each water sample were calculated by using following equation (Richards 1954). 
Fig. 8 a, b Variation of chloride $(\mathrm{Cl})$ for post-monsoon (October 2009) and premonsoon (April 2010) in the study area
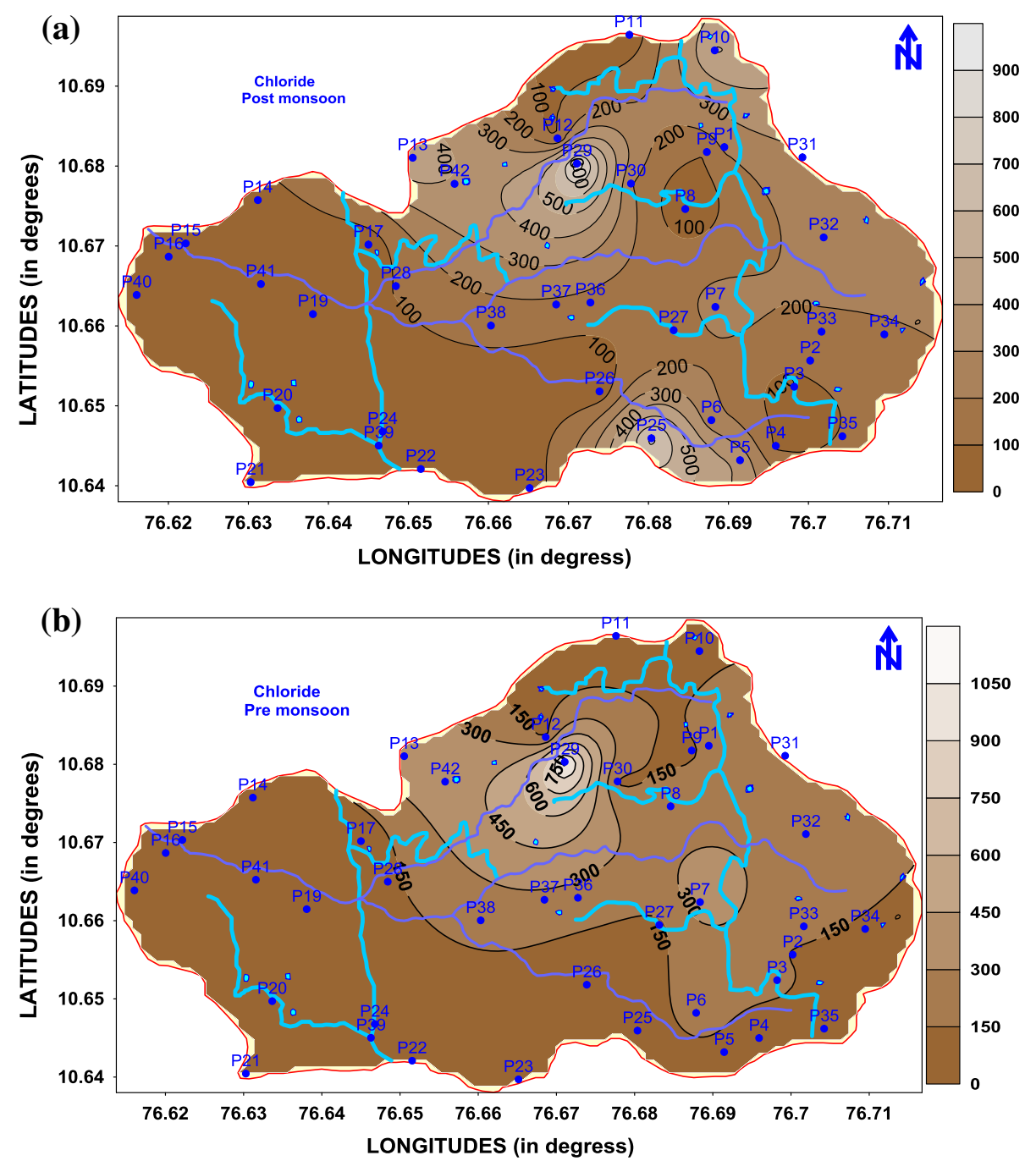

$\mathrm{SAR}=\frac{\mathrm{Na}}{\sqrt{(\mathrm{Ca}+\mathrm{Mg}) / 2}}$

where the concentration are reported in milligrams per liter.

The waters having SAR values $<10$ are considered excellent, $10-18$ as good, $18-26$ as fair, and above 26 are unsuitable for irrigation use (USDA 1954). In the present study, a total of 25 samples from post-monsoon and 20 samples from pre-monsoon fall in excellent class, i.e. the SAR values $<10$. The post-monsoon four samples fall in good class and from pre-monsoon seven water samples. Well No P4 in post-monsoon and P13 in pre-monsoon fall in fair class. The samples that are graded as excellent and good are used for irrigation. Based on sodium percentage, the prominent groundwater samples are suitable for irrigation (Table 6).
Residual sodium carbonate (RSC)

In water having high concentration of bicarbonate, there is tendency for calcium and magnesium to precipitate as carbonate. To meet these effects experimental parameters termed as RSC (Eaton 1950) was used. Residual sodium carbonate is calculated as follows:

$\mathrm{RSC}=\left(\mathrm{CO}_{3}+\mathrm{HCO}_{3}-(\mathrm{Ca}+\mathrm{Mg})\right)$

If RSC exceeds $2.5 \mathrm{meq} / \mathrm{L}$, the water is generally unsuitable for irrigation. If the value of RSC is between 1.25 and $2.5 \mathrm{meq} / \mathrm{L}$, the water is marginally suitable, while a value $<1.25 \mathrm{meq} / \mathrm{L}$ indicates good water quality (USDA 1954). It is observed from Table 6 that, all the samples from post-monsoon and 25 samples from pre-monsoon fall in good class which is safe for usage. The four samples $(\mathrm{P} 8$, $\mathrm{P} 10, \mathrm{P} 21$, and P27) from pre-monsoon fall in doubtful class. 
Table 6 Classification of groundwater sample for irrigation use on the basis of EC, SAR, RSC, KR, and SSP

\begin{tabular}{|c|c|c|c|c|}
\hline \multirow[t]{2}{*}{ Parameters } & \multirow[t]{2}{*}{ Range } & \multirow[t]{2}{*}{ Water class } & \multicolumn{2}{|c|}{ Samples (\%) } \\
\hline & & & $\begin{array}{l}\text { Post- } \\
\text { monsoon }\end{array}$ & $\begin{array}{l}\text { Pre- } \\
\text { monsoon }\end{array}$ \\
\hline \multirow[t]{4}{*}{ EC } & 250 & Excellent & Nil & Nil \\
\hline & $251-750$ & Good & 33 & 17 \\
\hline & $751-2,250$ & Permissible & 67 & 61 \\
\hline & $2,251-6,000$ & Doubtful & Nil & 17 \\
\hline \multirow[t]{4}{*}{ SAR } & 10 & Excellent & 100 & 100 \\
\hline & 18 & Good & Nil & Nil \\
\hline & $18-26$ & Doubtful & Nil & Nil \\
\hline & 26 & Unsuitable & Nil & Nil \\
\hline \multirow[t]{3}{*}{ RSC } & $<1.25$ & Good & 95 & 95 \\
\hline & $1.25-2.50$ & Doubtful & Nil & Nil \\
\hline & 2.5 & Unsuitable & 05 & 05 \\
\hline \multirow[t]{3}{*}{ KR } & $<1$ & Suitable & 22 & 25 \\
\hline & $1-2$ & Marginal suitable & 08 & 04 \\
\hline & $>2$ & Unsuitable & Nil & Nil \\
\hline \multirow[t]{2}{*}{ SSP } & $<50$ & Good & 86 & 75 \\
\hline & $>50$ & Unsuitable & 14 & 25 \\
\hline
\end{tabular}

Soluble sodium percentage (SSP)

Wilcox (1955) has proposed classification scheme for rating irrigation waters on the basis of SSP. The SSP was calculated by using following formula:
$\mathrm{SSP}=\frac{\mathrm{Na}}{\mathrm{Ca}+\mathrm{Mg}+\mathrm{Na}} \times 100$

The values of SSP $<50$ indicate good quality of water and higher values (i.e. $>50$ ) show that the water is unsafe for irrigation (USDA 1954). It is observed from (Table 6) that, the seven samples (P16, P22, P11, P19, P8, P17, and P4) from post-monsoon exceeds above 50, whereas in the case of pre-monsoon, there are only four samples (P10, $\mathrm{P} 27$, P8, and P13), which are above 50. All the groundwater samples have SSP values $<50$, which can be graded as good quality for irrigation.

Kelly's ratio (KR)

The Kelly's ratio of unity or $<1$ is indicative of good quality of water for irrigation whereas above one is suggestive of unsuitability for agricultural purpose due to alkali hazards (Karanth 1987). Kelly's ratio was calculated by using the following expression

$\mathrm{KR}=\frac{\mathrm{Na}}{\mathrm{Ca}+\mathrm{Mg}}$

It is observed from Table 6 that, the eight samples (P21, P16, P22, P11, P19, P8, P17, and P4) from post-monsoon exceeds above unity, whereas in the case of pre monsoon, there are only four samples (P10, P27, P8, and P13), which are above unity. The other samples in the study area are good for irrigation regarding alkali hazards.
Fig. 9 Classification of groundwater based on Wilcox diagram for post-monsoon (October 2009) and premonsoon (April 2010) periods

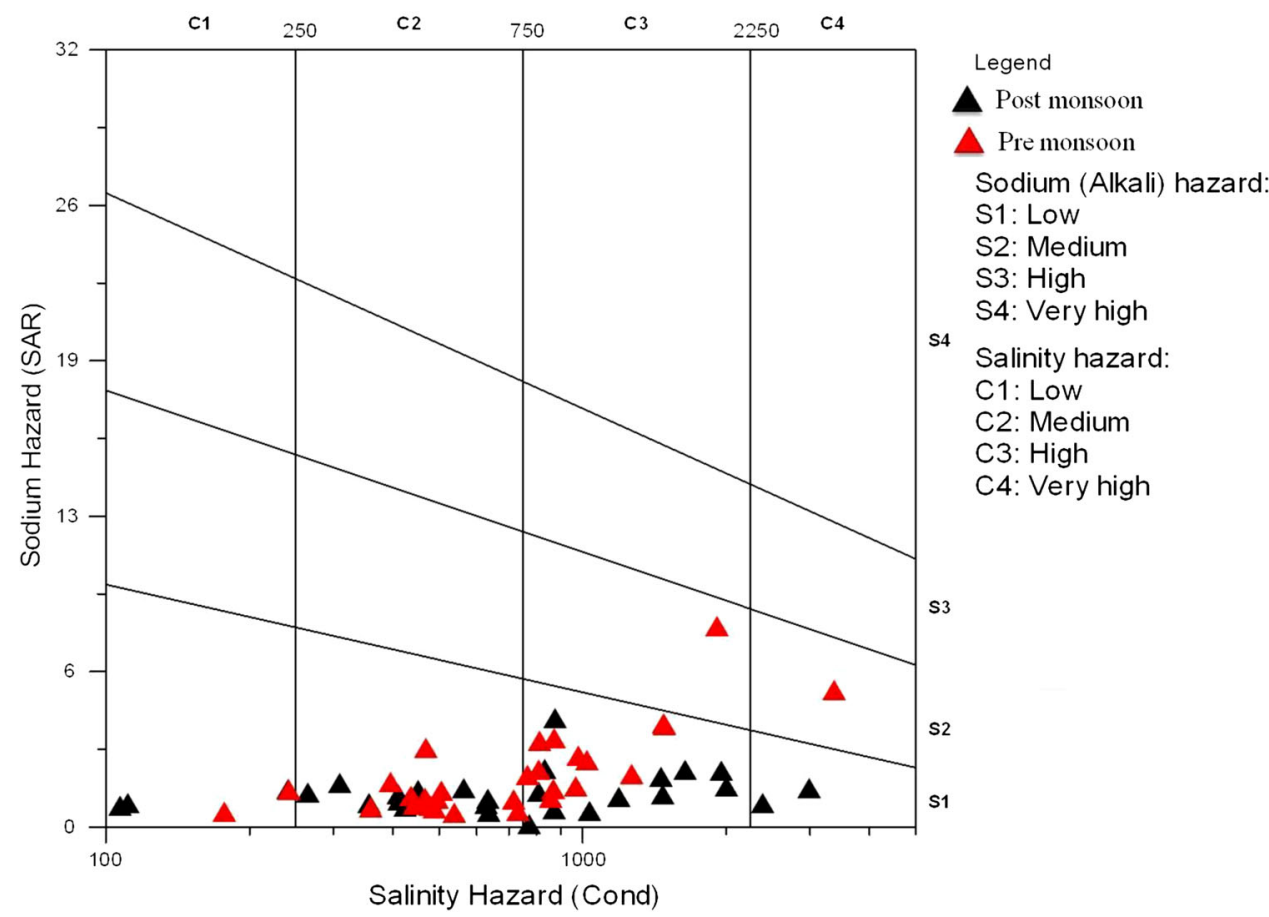






Fig. 10 Doneen Plot for groundwater samples for post-monsoon (October 2009) and pre-monsoon (April 2010) periods

Permeability index (PI)

Long-term use of irrigation water affects soil permeability. It depends on various factors like total soluble salt, sodium, calcium, magnesium, and bicarbonate content of the water. Doneen (1964) classified irrigation waters into three classes based on the PI. The PI has been computed and plotted on Doneen chart (Fig. 10) and is formulated as

$\mathrm{PI}=\frac{(\mathrm{Na}+\mathrm{K})+\sqrt{\mathrm{HCO}_{3}}}{\mathrm{Ca}+\mathrm{Mg}+\mathrm{Na}+\mathrm{K}} \times 100$

All the ions are represented in meq/L. As per the PI of groundwater samples in the study area fall in the fields of Class I and II and are described as having excellent to good permeability (Fig. 12). However, the entire water samples are classified as having excellent (Class I) permeability from both pre- and post-monsoon (Fig. 10).

Water quality index (WQI)

Water quality index is important because it arises first from the need to share and communicate with the public in a consistent manner of monitoring ambient water. Second, it is associated with the need to provide a general means of comparing and ranking various bodies of water throughout the region. One of the benefits of the index is elimination of jargon and technical complexity in describing water quality. The index strives to reduce an analysis of many factors into a simple statement. The WQI is founded on three issues involving the measurement of the attainment of water quality objectives. The factors are (1) number of objectives that are not met, (2) frequency with which objectives are not met, and (3) the amount by which objectives are not met. The WQI was calculated for groundwater and surface water samples for pre-monsoon and post-monsoon period taking into consideration six parameters, namely $\mathrm{pH}$, electrical conductivity, total dissolved solids, nitrates, sulfates and total hardness. The weighted arithmetic WQI was calculated as follows and given in Table 7 for post-monsoon and pre-monsoon period, respectively.

$\mathrm{WQI}=\left[\sum\left(q_{i} \cdot w_{i}\right) / \sum w_{i}\right]$

Further, water quality status based on WQI (Ramakrishnaiah et al. 2009; Bhuven et al. 2011; Kushtagi and Srinivas 2012) was classified as excellent (WQI <50), good $(\mathrm{WQI}=50-100), \quad$ poor $(\mathrm{WQI}=100-200)$, very poor $(\mathrm{WQI}=200-300)$, and water unsuitable for drinking and irrigation (WQI $>300$ ). Water samples of the study area fall in the category of excellent and good water with a percentage of 10.34 in post-monsoon and 3.44 in pre-monsoon, while the rest were unsuitable for drinking and irrigation use (Table 8).

Gibbs plot

The groundwater quality for drinking and irrigation purposes was assessed based on WHO (1984), standards. The quality of groundwater is significantly changed by the influence of weathering and anthropogenic inputs. The Gibbs diagram is widely used to establish the relationship of water composition and aquifer lithological characteristics (Gibbs 1970). Three distinct fields, such as precipitation dominance, evaporation dominance, and rock-water interaction dominance areas are shown in the Gibbs diagram. The predominant samples for both post- and premonsoon fall in the rock-water interaction dominance field of the Gibbs diagram (Fig. 11a, b). The rock-water interaction dominance field indicates the interaction between rock chemistry and the chemistry of the percolation waters under the subsurface.

Gibbs ratio $\mathrm{I}($ for anion $)=\mathrm{Cl} /\left(\mathrm{Cl}+\mathrm{HCO}_{3}\right)$

Gibbs ratio II (for cation) $=\mathrm{Na}^{+}+\mathrm{K}^{2+} /$

$$
\left(\mathrm{Na}^{+}+\mathrm{K}^{2+}+\mathrm{Ca}^{2+}\right)
$$

Hydrochemical facies

The hydrochemical evolution of groundwater can be understood by plotting the major cations and anions in piper trilinear diagram (Piper 1944). This diagram reveals similarities and dissimilarities among groundwater samples because those with similar qualities will tend to plot 
Table 7 Calculation of SAR, KR, RSC, SSP, PI, and WQI of groundwater for post-monsoon and pre-monsoon period

\begin{tabular}{|c|c|c|c|c|c|c|c|c|c|c|c|c|c|c|}
\hline \multirow[t]{2}{*}{ Well ID } & \multicolumn{7}{|c|}{ Post-monsoon period } & \multicolumn{7}{|c|}{ Pre-monsoon period } \\
\hline & SAR & SSP & KR & RSC & PI & WQI (WHO) & WQI (BIS) & SAR & SSP & KR & RSC & PI & WQI (WHO) & WQI (BIS) \\
\hline P1 & 7.638 & 32.717 & 0.49 & -1.661 & 57.24 & 273.933 & 363.039 & 16.395 & 41.686 & 0.715 & -1.971 & 50.59 & 263.164 & 558.555 \\
\hline $\mathrm{P} 2$ & 0.677 & 4.960 & 0.05 & -3.013 & 19.97 & 190.438 & 204.995 & 7.113 & 27.118 & 0.372 & -4.700 & 32.63 & 215.112 & 338.380 \\
\hline P3 & 6.224 & 40.218 & 0.67 & -0.379 & 57.21 & 98.143 & 135.236 & 5.141 & 28.970 & 0.408 & 0.009 & 39.43 & 89.533 & 147.072 \\
\hline $\mathrm{P} 4$ & 25.125 & 66.924 & 2.02 & 1.226 & 75.31 & 187.217 & 372.563 & 4.705 & 25.699 & 0.346 & -1.165 & 34.81 & 92.257 & 155.859 \\
\hline P5 & 13.280 & 46.863 & 0.88 & -2.864 & 53.68 & 264.527 & 397.420 & 9.256 & 35.451 & 0.549 & -0.057 & 42.57 & 192.312 & 314.484 \\
\hline P6 & 3.857 & 21.236 & 0.27 & -3.456 & 33.34 & 250.836 & 289.940 & 7.606 & 33.276 & 0.499 & -0.916 & 41.33 & 130.016 & 228.447 \\
\hline P7 & 11.742 & 42.839 & 0.75 & -0.574 & 53.32 & 237.524 & 363.244 & 16.186 & 42.948 & 0.753 & -0.096 & 47.80 & 202.836 & 472.528 \\
\hline P8 & 10.306 & 59.603 & 1.48 & 0.248 & 75.72 & 19.013 & 7.983 & 13.242 & 56.319 & 1.289 & 1.547 & 65.87 & 84 & 7.141 \\
\hline P9 & 4.145 & 23.231 & 0.30 & -0.351 & 39.97 & 182.060 & 239.150 & 11.347 & 36.918 & 0.585 & -2.881 & 42.32 & 201.488 & 386.340 \\
\hline 10 & 8.454 & 31.987 & 0.47 & -1.750 & 40.84 & 123.972 & 276.789 & 14.466 & 50.635 & 1.026 & 1.324 & 57.72 & 123.242 & 263.313 \\
\hline 11 & 8.349 & 54.417 & 1.19 & 0.220 & 72.82 & 47.897 & 4.827 & 7.621 & 43.320 & 0.764 & 0.739 & 54.68 & 59.276 & 5.573 \\
\hline P12 & 6.598 & 35.128 & 0.54 & -1.015 & 49.86 & 164.305 & 222.039 & 4.848 & 20.348 & 0.255 & -2.974 & 27.23 & 183.327 & 286.408 \\
\hline P13 & 13.531 & 45.879 & 0.85 & -5.893 & 51.55 & 353.680 & 482.946 & 31.018 & 60.659 & 1.542 & -4.073 & 63.38 & 249.139 & 656.918 \\
\hline P14 & 5.311 & 29.320 & 0.41 & -0.634 & 45.22 & 166.820 & 220.896 & 2.570 & 11.920 & 0.135 & -2.264 & 19.70 & 159.747 & 248.922 \\
\hline P15 & 7.023 & 42.624 & 0.74 & -0.285 & 60.81 & 116.584 & 158.688 & 6.046 & 31.360 & 0.457 & 0.042 & 41.72 & 117.393 & 185.595 \\
\hline P16 & 8.863 & 51.360 & 1.06 & 0.285 & 67.61 & 95.654 & 142.161 & 4.195 & 17.885 & 0.218 & -2.759 & 24.63 & 158.104 & 274.213 \\
\hline P17 & 8.580 & 61.755 & 1.61 & 0.604 & 85.74 & 14.332 & 44.938 & 5.752 & 38.887 & 0.636 & 0.264 & 51.78 & 29.477 & 73.139 \\
\hline P19 & 5.756 & 57.999 & 1.38 & 0.299 & 92.07 & 41.746 & 46.397 & 3.303 & 18.030 & 0.220 & -0.220 & 27.60 & 65.860 & 135.894 \\
\hline $\mathrm{P} 20$ & 3.566 & 21.231 & 0.27 & -1.795 & 35.97 & 0.319 & 16.533 & 2.892 & 17.880 & 0.218 & 0.670 & 30.43 & 138.095 & 178.795 \\
\hline $\mathrm{P} 21$ & 4.923 & 50.251 & 1.01 & 0.482 & 80.64 & 216.654 & 250.253 & 2.950 & 28.723 & 0.403 & 1.519 & 53.46 & 22.410 & 43.841 \\
\hline $\mathrm{P} 22$ & 13.197 & 52.121 & 1.09 & -0.502 & 77.82 & 42.929 & 56.697 & 8.890 & 34.810 & 0.534 & -1.243 & 51.90 & 125.483 & 252.878 \\
\hline $\mathrm{P} 23$ & 7.625 & 44.135 & 0.79 & 0.229 & 60.11 & 125.552 & 234.932 & 5.292 & 28.927 & 0.407 & 0.933 & 40.41 & 116.720 & 177.416 \\
\hline $\mathrm{P} 24$ & 5.655 & 39.203 & 0.64 & -0.160 & 56.95 & 90.092 & 141.378 & 3.363 & 21.702 & 0.277 & 0.187 & 33.64 & 68.947 & 114.418 \\
\hline $\mathrm{P} 25$ & 5.669 & 18.249 & 0.22 & -4.504 & 23.51 & 109.070 & 139.329 & 3.352 & 18.467 & 0.227 & -0.811 & 27.78 & 88.973 & 152.766 \\
\hline $\mathrm{P} 26$ & 4.663 & 31.177 & 0.45 & 0.602 & 50.96 & 726.355 & 837.096 & 2.866 & 15.263 & 0.180 & -0.334 & 26.26 & 87.160 & 158.075 \\
\hline P27 & 8.112 & 43.693 & 0.78 & 0.459 & 59.39 & 82.693 & 123.342 & 15.289 & 51.065 & 1.044 & 1.726 & 58.17 & 142.574 & 296.493 \\
\hline $\mathrm{P} 28$ & 8.979 & 48.274 & 0.93 & -0.084 & 61.40 & 125.045 & 183.054 & 8.201 & 33.090 & 0.495 & -0.977 & 40.22 & 114.817 & 236.054 \\
\hline P29 & 8.657 & 27.261 & 0.37 & -8.357 & 34.01 & 81.695 & 139.702 & 19.314 & 32.466 & 0.481 & -27.041 & 34.29 & 385.734 & $1,138.107$ \\
\hline P30 & 7.200 & 33.267 & 0.50 & -1.872 & 44.34 & 379.303 & 574.543 & 12.854 & 45.241 & 0.826 & -0.209 & 52.79 & 190.212 & 329.913 \\
\hline
\end{tabular}

Table 8 Water quality classification based on WQI value

\begin{tabular}{lllll}
\hline Class & $\begin{array}{l}\text { WQI } \\
\text { value }\end{array}$ & $\begin{array}{l}\text { Water quality } \\
\text { status }\end{array}$ & $\begin{array}{l}\text { Post-monsoon } \\
(\%)\end{array}$ & $\begin{array}{l}\text { Pre-monsoon } \\
(\%)\end{array}$ \\
\hline I & $<50$ & Excellent & 10.34 & 3.44 \\
II & $50-100$ & Good water & 13.79 & 3.44 \\
III & $100-200$ & Poor water & 24.13 & 37.93 \\
IV & $200-300$ & Very poor water & 27.58 & 27.58 \\
V & $>300$ & Unsuitable water & 24.13 & 27.58 \\
\hline
\end{tabular}

together as groups (Todd 2001). This diagram is very useful in bringing out chemical relationships among groundwater in more definite terms (Walton 1970). The geochemical evolution can be understood from the Piper plot, which has been divided into six subcategories viz.
Type-I $\left(\mathrm{Ca}^{2+}-\mathrm{Mg}^{2+}-\mathrm{HCO}_{3}^{-} \quad\right.$ type $), \quad$ Type-II $\quad\left(\mathrm{Na}^{+}-\right.$ $\mathrm{Cl}^{-}$type), Type-III (Mixed $\mathrm{Ca}^{2+}-\mathrm{Na}^{+}-\mathrm{HCO}_{3}^{-}$type), TypeIV (Mixed $\mathrm{Ca}^{2+}-\mathrm{Na}^{+}-\mathrm{Cl}^{-}$type), Type- $\mathrm{V}\left(\mathrm{Ca}^{2+}-\mathrm{Mg}^{2+}-\right.$ $\mathrm{Cl}^{-}$type) and Type-VI $\left(\mathrm{Na}^{+}-\mathrm{HCO}_{3}^{-}\right.$type $)$.

As per the classification of Piper diagram, the groundwater samples from the study area for post-monsoon (October 2009) are classified into the hydrochemical facies which are arranged in the decreasing order of abundance as Type-I $\left(\mathrm{Ca}^{2+}-\mathrm{Mg}^{2+}-\mathrm{HCO}_{3}^{-}\right.$type), Type-III (Mixed $\mathrm{Ca}^{2+}$ $\mathrm{Na}^{+}-\mathrm{HCO}_{3}^{-}$type $)$and Type- $\mathrm{V}\left(\mathrm{Ca}^{2+}-\mathrm{Mg}^{2+}-\mathrm{HCO}_{3}^{-}\right)$. Whereas the II, IV and VI types of groundwater samples are far less in post-monsoon period (Fig. 12). During pre-monsoon (April 2010), the samples are classified into Type-I $\left(\mathrm{Ca}^{2+}-\mathrm{Mg}^{2+}-\mathrm{Na}-\mathrm{Cl}-\mathrm{HCO}_{3}^{-}\right.$type), Type-III (Mixed $\mathrm{Ca}^{2+}-$ $\mathrm{Na}^{+}-\mathrm{Cl}-\mathrm{HCO}_{3}^{-}$type $)$and Type- $\mathrm{V}\left(\mathrm{Ca}^{2+}-\mathrm{Mg}^{2+}-\mathrm{HCO}_{3}^{-}\right)$. 

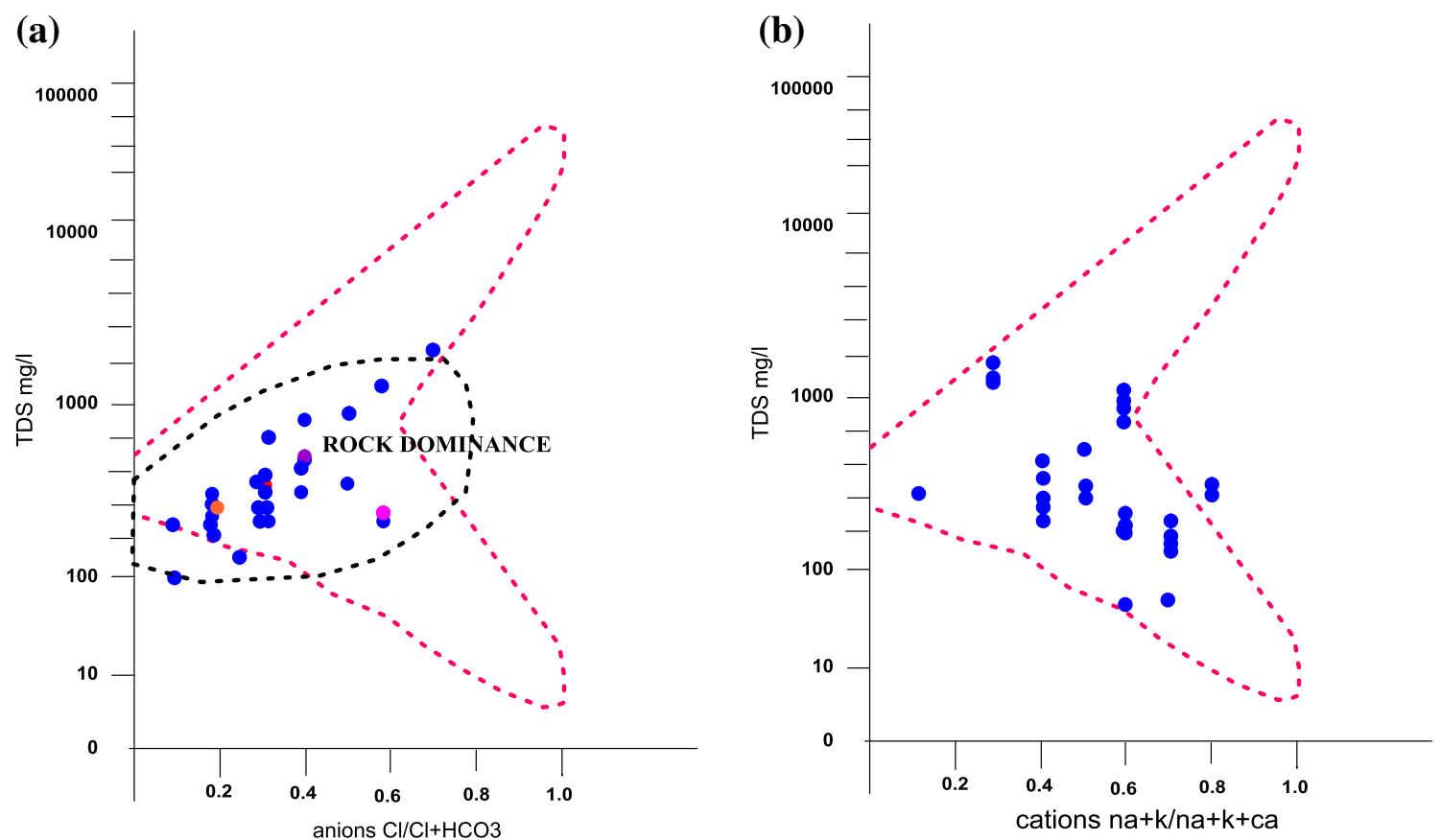

Fig. 11 a, b Gibbs Plots for groundwater samples for post-monsoon (October 2009) and pre-monsoon (April 2010) periods

Fig. 12 Piper Trilinear Plots for groundwater samples for post-monsoon (October 2009) and pre-monsoon (April 2010) periods

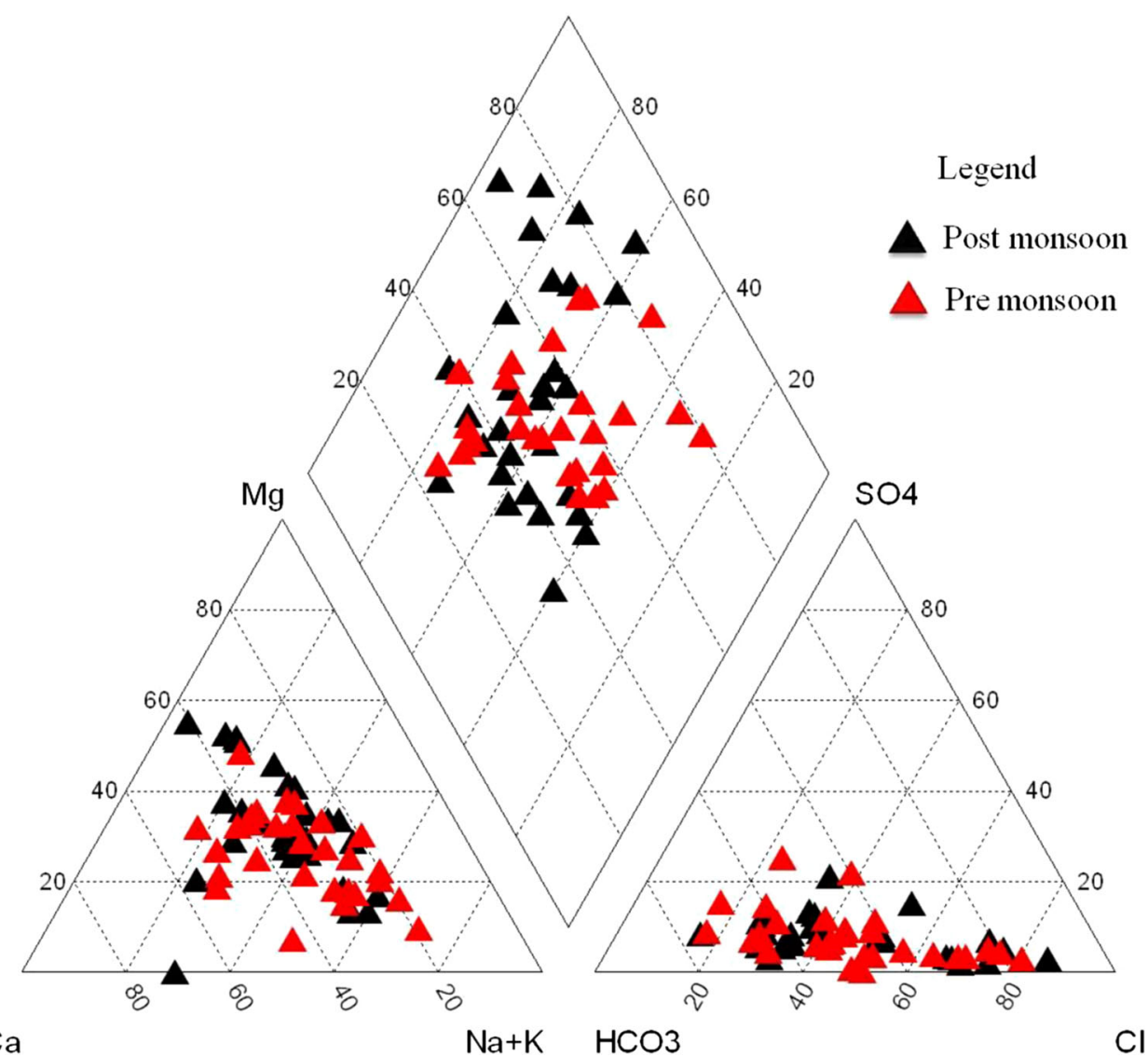

From another point of view, $100 \%$ of the plots clustered in Type-I $\left(\mathrm{Ca}+\mathrm{Mg}+\mathrm{Na}-\mathrm{Cl}+\mathrm{HCO}_{3}\right)$ facies of the Piper's diagram. In this study, the dominant ions are $\mathrm{Cl}, \mathrm{Na}$ with $\mathrm{Ca}$, and $\mathrm{HCO}_{3}$ ions following. Generally, groundwater tends to acquire chemical compositions similar to that of seawater (that is more dissolved and relative increase in 
Table 9 Cross correlation matrix of water quality data for post-monsoon season (October2009)

Table 10 Cross-correlation matrix of water quality data for pre-monsoon season (April2010)

\begin{tabular}{|c|c|c|c|c|c|c|c|c|c|c|c|c|}
\hline & $\mathrm{pH}$ & EC & TDS & $\mathrm{HCO}_{3}$ & $\mathrm{Cl}$ & $\mathrm{F}$ & $\mathrm{NO}_{3}$ & $\mathrm{SO}_{4}$ & $\mathrm{Na}$ & $\mathrm{K}$ & $\mathrm{Ca}$ & $\mathrm{Mg}$ \\
\hline $\mathrm{pH}$ & 1 & 0.17 & 0.17 & 0.39 & 0.09 & 0.53 & -0.12 & 0.25 & 0.14 & 0.06 & 0.19 & 0.34 \\
\hline $\mathrm{EC}$ & & 1 & 1 & 0.76 & 0.97 & 0.37 & 0.47 & 0.58 & 0.68 & 0.11 & 0.95 & 0.75 \\
\hline TDS & & & 1 & 0.76 & 0.97 & 0.37 & 0.47 & 0.58 & 0.68 & 0.11 & 0.95 & 0.75 \\
\hline $\mathrm{HCO}_{3}$ & & & & 1 & 0.65 & 0.72 & 0.07 & 0.51 & 0.64 & 0.22 & 0.82 & 0.66 \\
\hline $\mathrm{Cl}$ & & & & & 1 & 0.24 & 0.38 & 0.47 & 0.57 & 0 & 0.94 & 0.76 \\
\hline $\mathrm{F}$ & & & & & & 1 & -0.2 & 0.28 & 0.37 & 0.23 & 0.44 & 0.3 \\
\hline $\mathrm{NO}_{3}$ & & & & & & & 1 & 0.36 & 0.59 & 0.13 & 0.23 & 0.14 \\
\hline $\mathrm{SO}_{4}$ & & & & & & & & 1 & 0.38 & 0.19 & 0.53 & 0.33 \\
\hline $\mathrm{Na}$ & & & & & & & & & 1 & 0.23 & 0.58 & 0.36 \\
\hline K & & & & & & & & & & 1 & 0.11 & -0.02 \\
\hline $\mathrm{Ca}$ & & & & & & & & & & & 1 & 0.73 \\
\hline $\mathrm{Mg}$ & & & & & & & & & & & & 1 \\
\hline
\end{tabular}

\begin{tabular}{|c|c|c|c|c|c|c|c|c|c|c|c|}
\hline & $\mathrm{pH}$ & $\mathrm{EC}$ & $\mathrm{HCO}_{3}$ & $\mathrm{Cl}$ & $\mathrm{F}$ & $\mathrm{NO}_{3}$ & $\mathrm{SO}_{4}$ & $\mathrm{Na}$ & K & $\mathrm{Ca}$ & $\mathrm{Mg}$ \\
\hline $\mathrm{pH}$ & 1 & 0 & 0.18 & -0.22 & 0.25 & -0.02 & 0.35 & -0.07 & 0.31 & -0.02 & 0.11 \\
\hline EC & & 1 & 0 & 0 & 0 & 0 & 0 & 0 & 0 & 0 & 0 \\
\hline $\mathrm{HCO}_{3}$ & & & 1 & 0.70 & 0.22 & 0.12 & 0.53 & 0.74 & 0.27 & 0.77 & 0.65 \\
\hline $\mathrm{Cl}$ & & & & 1 & -0.17 & 0.23 & 0.3 & 0.89 & -0.009 & 0.91 & 0.34 \\
\hline $\mathrm{F}$ & & & & & 1 & -0.01 & 0.29 & -0.02 & 0.12 & -0.17 & 0.19 \\
\hline $\mathrm{NO}_{3}$ & & & & & & 1 & 0.10 & 0.56 & 0.19 & 0.11 & 0.14 \\
\hline $\mathrm{SO}_{4}$ & & & & & & & 1 & 0.42 & -0.06 & 0.40 & 0.44 \\
\hline $\mathrm{Na}$ & & & & & & & & 1 & 0.15 & 0.79 & 0.42 \\
\hline K & & & & & & & & & 1 & 0.09 & -0.09 \\
\hline $\mathrm{Ca}$ & & & & & & & & & & 1 & 0.40 \\
\hline $\mathrm{Mg}$ & & & & & & & & & & & 1 \\
\hline
\end{tabular}

chloride ion) the longer it remains underground and the further it travels.

\section{Correlation analyses}

A high correlation coefficient means a good relationship between two variables, and a correlation coefficient around zero means no relationship. Positive values of $r$ indicate a positive relationship while negative values indicate an inverse relationship. The correlation coefficient matrix of analyzed ions for post-monsoon (October 2009) and pre-monsoon (April 2010) seasons is shown in Tables 9 and 10. The correlation coefficient matrix was calculated and it has been observed that during postmonsoon season (October 2009), the correlation between $\mathrm{HCO}_{3}$ and EC/TDS; $\mathrm{Cl}$ and EC/TDS; $\mathrm{HCO}_{3}$ and $\mathrm{F} ; \mathrm{Na}$ with EC/TDS; Ca with EC/TDS; and Mg with EC/TDS shows with high positive correlation, and during premonsoon season (April 2010) the correlation between $\mathrm{HCO}_{3}$ with $\mathrm{Cl}$; $\mathrm{Na}$ with $\mathrm{Cl}$; $\mathrm{Ca}$ with $\mathrm{Cl}$; and $\mathrm{Ca}$ with $\mathrm{Na}$ shows high correlation, while for other parameters shows weak negative or no correlation.

\section{Conclusion}

The concentrations of cations and anions are within the allowable limits for drinking water standards except a few samples. The suitability of water for irrigation is evaluated based on SAR, RSC, and salinity hazards. Most of the sample falls in the suitable range for irrigation purpose based on SAR, KR, SSP, and RSC values, but few samples that are exceeding the permissible limits are observed to be in different kind of geological and anthropogenic activities were carried out near the samples in the study area. Based on hydrochemical facies, most water type dominates in the study area is $\mathrm{Na}-\mathrm{Ca}-\mathrm{CO}_{3}-\mathrm{HCO}_{3}-\mathrm{Cl}$ facies during postmonsoon seasons. From the different plots, it is observed that the groundwater samples are alkaline earths $\left(\mathrm{Ca}^{2+}\right.$ and $\left.\mathrm{Mg}^{2+}\right)$ significantly exceed the alkalis $\left(\mathrm{Na}^{+}\right.$and $\left.\mathrm{K}^{+}\right)$and strong acids $\left(\mathrm{Cl}^{-}\right.$and $\left.\mathrm{SO}_{4}{ }^{-}\right)$exceed the weak acids $\left(\mathrm{HCO}_{3}\right.$ and $\mathrm{CO}_{3}$ ). Gibb's diagram reveals that most of the groundwater sample fall in the rock dominance field. The subsurface water chemistry indicates the dominance of interaction between rock chemistry and the chemistry of the percolation waters. The correlation coefficient between $\mathrm{HCO}_{3}$ with EC/TDS; $\mathrm{Cl}$ and EC/TDS; $\mathrm{HCO}_{3}$ and $\mathrm{F} ; \mathrm{Na}$ 
with EC/TDS; Ca with EC/TDS; Mg with EC/TDS; $\mathrm{HCO}_{3}$ with $\mathrm{Cl}$; $\mathrm{Na}$ with $\mathrm{Cl}$; $\mathrm{Ca}$ with $\mathrm{Cl}$; and $\mathrm{Ca}$ with $\mathrm{Na}$ shows strong positive correlation.

Acknowledgments The authors express their thanks to Director, NGRI, Hyderabad for his continuous support for the research activity. Authors are also thankful to the staff of the Kerala Government for their help rendered and cooperated during the field work. Authors are also thankful to the honorable reviewers for their scientific comments to improve the content of the manuscript. Authors are thankful to the Editor and the Handling Editor of the Journal for their cooperation and encouragement.

Open Access This article is distributed under the terms of the Creative Commons Attribution License which permits any use, distribution, and reproduction in any medium, provided the original author(s) and the source are credited.

\section{References}

Akbal F, Gurel L, Bahadir T, Guler I, Bakan G, Buyukgungor H (2011) Water and sediment quality assessment in the mid-Black Sea coast of Turkey using multivariate statistical techniques. Environ Earth Sci 64(5):1387-1395

Alagbe SA (2006) Preliminary evaluation of hydrochemistry of the Kalambain Formation, Sokoto Basin, Nigeria. Environ Geol 51:39-45

APHA (1995) Standard methods for the examination of water and waste water, 19th edn. APHA, Washington DC

Appelo CAJ, Postma D (2005) Geochemistry, groundwater and pollution, 2nd edn. Balkema publishers, Leiden, p 404

Aravindan S, Manivel M, Chandrasekar SVN (2004) Ground water quality in the hard rack area of the Gadilam river basin, Tamil Nadu. J Geol Soc India 63(6):625-635

Aravindan S, Shankar K, Poovalinga Ganesh B, Dharani Rajan K (2010) Hydrogeochemical mapping of in the hard rock area of Gadilam River basin, using GIS technique, Tamil Nadu. Indian J Appl Geochem 12(2):209-216

Bhardwaj V, Sen Singh D (2011) Surface and groundwater quality characterization of Deoria District, Ganga Plain, India. Environ Earth Sci 63(2):383-395

Bhuven NT, Macwan JEM, Soni Chirag K (2011) Assessment of water quality index of small lake in south Gujarat region, India. In: Proceedings of ISEM-2011, Thailand

BIS (1991) Specifications for drinking water IS: 10500:1991, Bureau of Indian Standards, New Delhi. In the soils of Tallinn (Estonia). Environ Geoche Health 22:173-193

Bohlke JK (2002) Groundwater recharge and agricultural contamination. Hydrogeol J 10:153-179

Brown E, Skougstand MW, Fishman MJ (1970) Methods for collection and analyses of water samples for dissolved minerals and gases. In: Techniques of Water Resources Investigation of the US Geological Survey 5

Carpenter SR, Caraco NF, Correll DL, Howarth RW, Sharpley AN, Smith VH (1998) Non point of surface waters with phosphorous and nitrogen. Ecol Appl 8(3):559-568

CGWB (2005) District Groundwater Management Studies of Palghat District, Kerala. In: Technical Report Series, Report No. 25/KR/ CGWB/2004-05

Dasgupta AM, Purohit KM (2001) Status of surface and groundwater quality of Mandiakadar-Part II: agricultural utilities. Pollut Res 20(2):219-225
Domenico PA, Schwartz FW (1990) Physical and chemical hydrology. Wiley, New York

Doneen LD (1964) Notes on water quality in agriculture. Published as a water science and engineering paper 4001, Department of Water Science and Engineering, University of California

Eaton FM (1950) Significance of carbonates in irrigation waters. Soil Sci 69:123-133

Gibbs RJ (1970) Mechanism controlling world water chemistry. Science 170:795-840

Griffioen J (2001) Potassium adsorption ratios as an indicator for the fate of agricultural potassium in groundwater. J Hydrol 254:244-254

Gupta S, Nayek S, Saha RN (2012) Major ion chemistry and metal distribution in coal mine pit lake contaminated with industrial effluents: constraints of weathering and anthropogenic inputs. Environ Earth Sci 67(7):2053-2061

Handa BK (1969) Description and classification of media for hydrogeochemical investigations. In: Symposium on groundwater studies in arid and semi-arid region. Roorkee

Jalali M (2005) Nitrates leaching from agricultural land in Hamadan, western Iran. Agric Ecosyst Environ 110:210-218

Jarvie HP, Whitton BA, Neal C (1998) Nitrogen and phosphorous in east coast British rivers: Speciation, sources and biological significant. Science Total Environ pp 210-211, 79-109. (World Acad Sci Eng Technol 522009 482)

Karanth KR (1987) Ground water assessment, development and management. Tata McGraw Hill Publishing Company Ltd., New Delhi, p 720

Khurshid SH, Hasan N, Zaheeruddin M (2002) Water quality status and environmental hazards in parts Environ Monit Assess of Yamuna-Karwan sub-basin of Aligarh-Mathura district, Uttar Predesh, India. J Appl Hydrol 14(4):30-37

Kolahchi Z, Jalali M (2006) Effect of water quality on the leaching of potassium from sandy soil. J Arid Environ 68:624-639

Kushtagi S, Srinivas P (2012) Studies on chemistry and water quality index of ground water in Chincoli Taluk, Gulbarga dist., Karnataka, India. Int J Environ Sci 2(3):1154-1160

Lehr JH, Gass TE, Pettyjohn WA, De Marre J (1980) Domestic water treatment. Mc Graw-hill Book Co., New Delhi, p 655

Machender G, Dhakate R, Reddy MN, Panduranga Reddy I (2013) Hydrogeochemical characteristics of Surface water (SW) and Groundwater $(\mathrm{GW})$ of the Chinnaeru river basin, Northern part of Nalgonda District, Andhra Pradesh, India. Environ Earth Sci. doi:10.1007/s12665-013-2665-8 (ONLINE)

Majumdar D, Gupta N (2000) Nitrate pollution of ground water and associated human health disorders. India $\mathbf{J}$ Environ Health 42(1):28-39

Naik PK, Awasthi AK, Anand AVSS, Behera PN (2009) Hydrogeochemistry of the Koyna River basin, India. Environ Earth Sci 59(3):613-629

Nosrati K, Van Den Eeckhaut EM (2012) Assessment of groundwater quality using multivariate statistical techniques in Hashtgerd Plain, Iran. Environ Earth Sci 65(1):331-344

Piper AM (1944) A graphical procedure in the geochemical interpretation of water analysis. Trans Am Geophys Union 25:914-923

Prasanna MV, Chidambaram S, Gireesh TV, Ali TVJ (2011) A study on hydrochemical characteristics of surface and sub-surface water in and around Perumal Lake, Cuddalore district, Tamil Nadu, South India. Environ Earth Sci 63(1):31-47

Purushotham D, Prakash MR, Rao AN (2011) Groundwater depletion and quality deterioration due to environmental impacts in Maheshwaram watershed of R.R. District, AP (India). Environ Earth Sci 62(8):1707-1721

Ramakrishnaiah CR, Sadashivaiah C, Ranganna G (2009) Assessment of water quality index for the groundwater in Tumkar Taluk, Karnataka State, India. E-J Chem 6(2):523-530 
Rao NS, Rao PS (2010) Major ion chemistry of groundwater in a river basin: a study from India. Environ Earth Sci 61(4):757-775

Rao PM, Sekhar P, Yadav YS (2004) Water Quality Studies on Kolleru Lake and Its Infalling Drains of A.P., India. In: Kumar Arvind (ed) Water pollution. APH Publishing Corporation, New Delhi, p 171

Rao NS, Subrahmanyam A, Kumar SR, Srinivasulu N, Rao GB, Rao PS, Reddy GV (2012) Geochemistry and quality of groundwater of Gummanampadu sub-basin, Guntur District, Andhra Pradesh, India. Environ Earth Sci 67(5):1451-1471

Richards LA (ed) (1954) Diagnosis and improvement of saline and alkali soils. In: USDA Handbook no. 60, Washington, pp 160

Shankar K, Aravindan S, Rajendran S (2010) GIS based groundwater quality mapping in Paravanar River Sub-Basin, Tamil Nadu, India. Int J Geomat Geosci 1(3):282-296

Shankar K, Aravindan S, Rajendran S (2011) Hydrogeochemistry of the Paravanar River Sub-basin, Cuddalore District, Tamil Nadu. E-J Chem 8(2):835-845

Sharma A, Singh AK, Kumar K (2012) Environmental geochemistry and quality assessment of surface and subsurface water of Mahi River basin, western India. Environ Earth Sci 65(4):1231-1250

Shivran HS, Dinesh Kumar D, Singh RV (2006) Improvement of water quality though biological denitrification. J Environ Sci Eng 48(1):57-60

Simeonov V, Stratis JA, Samara C, Zachariadis G, Voutsa D, Anthemidis A, Sofoniou M, Kouimtzis TH (2003) Assessment of the surface water quality in Northern Greece. Water Res 37:4119-4124

Singh AK, Tewary BK, Sinha A (2011) Hydrochemistry and quality assessment of ground-water in Part of NOIDA Metropolitan City, Uttar Pradesh. J Geol Soc India 78:523-540

Soman K (1977) Geology of Kerala. Geological Society of India, Bangalore, p 280

Sreedevi PD (2004) Groundwater quality of Pageru river basin, Cuddepah district, Andhra Pradesh. J Geol Soc India 64(5):619-636
Subba Rao N (2006) Seasonal variation of groundwater quality in a part of Guntur district, Andhra Pradesh, India. Environ Geol 49:413-429

Sujatha D, Reddy RB (2003) Quality characterization of groundwater in the south-eastern part of the Ranja Reddy district, Andhra Pradesh, India. Environ Geol 44(5):579-586

Sunitha V, Sudarsha V, Reddy RB (2005) Hydrogeochemistry of groundwater, Gooty area, Anantapur district, Andhra Pradesh, India. Pollut Res 24(1):217-224

Suyash K, Pawar NJ (2011) Site-specific accentuation of heavy metals in groundwaters from Ankaleshwar industrial estate, India. Environ Earth Sci 64(2):557-566

Takem GE, Chandrasekharam D, Ayonghe SN, Thambidurai P (2010) Pollution character-ristics of alluvial groundwater from springs and bore wells in semi-urban informal settlements of Douala, Cameroon, Western Africa. Environ Earth Sci 61(2):287-298

Todd DK (1980) Groundwater Hydrology, 2nd edn. Wiley, New York, p 535

Todd DK (2001) Groundwater hydrology. Wiley, Canada, pp 280-281

USDA (1954) Diagnosis and improvement of saline and alkali soils. U.S. Salinity Laboratory Staff, Government Printing Office, Washington, DC

Walton WC (1970) Groundwater resources evaluation. McGraw-Hill Book Co., New York

WHO (1984) Guidelines to drinking water quality. World Health Organisation, Geneva 186

WHO (1993) Guidelines for drinking water quality 1 Recommendations, 2nd edn. World Health Organization, Geneva

Wilcox LV (1955) Classification and use of irrigation waters. US Department of Agriculture Circular 969, Washington, DC, p 19 